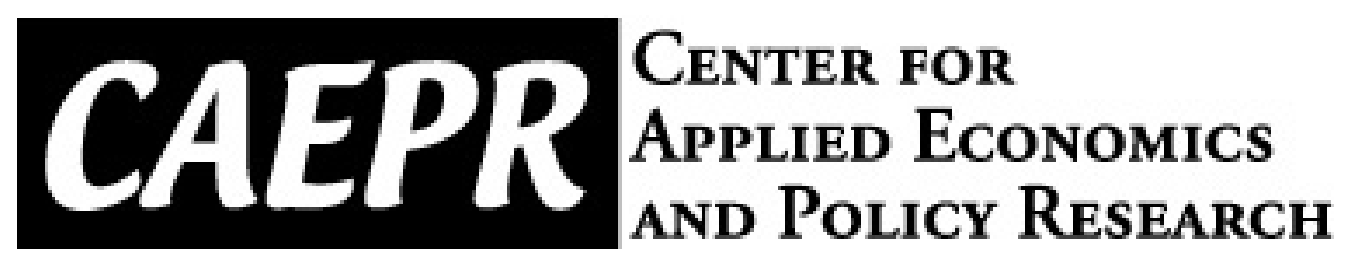

CAEPR Working Paper

\#012-2009

\title{
DYNAMICS OF FISCAL FINANCING IN THE UNITED STATES
}

\section{ERIC M. LEEPER, MICHAEL PLANTE, AND NORA TRAUM \\ Indiana University}

July 7, 2009

This paper can be downloaded without charge from the Social Science Research Network electronic library at: http://ssrn.com/abstract=1456361.

The Center for Applied Economics and Policy Research resides in the Department of Economics at Indiana University Bloomington. CAEPR can be found on the Internet at:

http://www.indiana.edu/ caepr. CAEPR can be reached via email at caepr@indiana.edu or via phone at 812-855-4050.

(C2008 by NAME. All rights reserved. Short sections of text, not to exceed two paragraphs, may be quoted without explicit permission provided that full credit, including $₫$ notice, is given to the source. 


\title{
DYNAMICS OF FISCAL FINANCING IN THE UNITED STATES
}

\author{
ERIC M. LEEPER, MICHAEL PLANTE, AND NORA TRAUM
}

\begin{abstract}
Dynamic stochastic general equilibrium models that include policy rules for government spending, lump-sum transfers, and distortionary taxation on labor and capital income and on consumption expenditures are fit to U.S. data under a variety of specifications of fiscal policy rules. We obtain several results. First, the best fitting model allows a rich set of fiscal instruments to respond to stabilize debt. Second, responses of aggregate variables to fiscal policy shocks under rich fiscal rules can vary considerably from responses that allow only non-distortionary fiscal instruments to finance debt. Third, based on estimated policy rules, transfers, capital tax rates, and government spending have historically responded strongly to government debt, while labor taxes have responded more weakly. Fourth, all components of the intertemporal condition linking debt to expected discounted surpluses - transfers, spending, tax revenues, and discount factors - display instances where their expected movements are important in establishing equilibrium. Fifth, debt-financed fiscal shocks trigger long lasting dynamics so that short-run multipliers can differ markedly from long-run multipliers, even in their signs.
\end{abstract}

JEL Codes: C11, E32, E62

\section{INTRODUCTION}

Countries around the world combatted the recession and financial crisis of 2007-2009 with aggressive fiscal actions, both to stimulate demand with lower taxes and higher government spending and to recapitalize banks through a variety of financial "rescue" plans. In the United States, the actions will raise the federal government fiscal deficit to over 13 percent of GDP in 2009. The Congressional Budget Office projects that these fiscal efforts together with the Obama administration's ambitious federal budget will push federal debt held by the public from 40 percent to 80 percent of GDP by 2019 [Congressional Budget Office (2009)]. Large run-ups in government debt have placed issues of fiscal financing on policy makers' front burners.

Rational expectations imply that economic agents' beliefs about how debt innovations are financed by fiscal instruments play a crucial role in determining the resulting equilibrium and

Date: July 7, 2009. We thank Timothy Cogley, Shu-Chun S. Yang, and participants at a presentation at the Reserve Bank of New Zealand for helpful comments. Department of Economics, Indiana University and NBER, eleeper@indiana.edu; Department of Economics, Indiana University and Ball State University, mplante@indiana.edu; Department of Economics, Indiana University, ntraum@indiana.edu. 
evolution of endogenous variables. Even in a simple real business cycle model, the impulse responses of economic variables following both fiscal policy and non-policy shocks depend on what fiscal instrument finances debt [Leeper and Yang (2008)]. Understanding which fiscal instruments have historically responded to debt and how quickly they have done so is essential to accurately predict the impacts of fiscal policy.

Although many theoretical conclusions about the effects of debt financing exist, empirical research that estimates how debt-financing policies affect the economy is scarce. ${ }^{1}$ Except for recent work by Chung and Leeper (2007), the identified VAR literature has ignored this issue. $^{2}$ Estimated dynamic stochastic general equilibrium models typically specify simple fiscal policies in ways that are unlikely to capture the dynamic interactions present in data [Kamps (2007), Ratto, Roeger, and in't Veld (2006), and Coenen and Straub (2004)].

This paper uses Bayesian methods to estimate and evaluate a dynamic stochastic general equilibrium (DSGE) model that incorporates a rich description of fiscal policy, including nontrivial debt dynamics. The paper's core contribution lies in its detailed specification of fiscal policy instruments and dynamic adjustments of fiscal instruments in response to the level of economic activity and to the state of government debt. We specify policy rules for capital, labor, and consumption taxes, government spending, and lump-sum transfers. The rules allow contemporaneous responses to output ("automatic stabilizers") and dynamic responses to government debt. By estimating a DSGE model that incorporates a rich description of fiscal policy, we are able to estimate how government debt has been financed historically and examine how adjustments in each fiscal instrument has affected the observed equilibrium.

Several recent papers employ Bayesian techniques to estimate fiscal policy rules and to understand the economic effects of fiscal policy [Forni, Monteforte, and Sessa (2009), Kamps (2007), Ratto, Roeger, and in't Veld (2006), and Coenen and Straub (2004)]. However, most of this literature has focused on modeling exogenous fiscal policy, where deficits are financed by lump-sum transfer adjustments. A series of papers demonstrates that in real business cycle-style models it can be seriously misleading to set aside debt dynamics by ignoring distortionary fiscal financing [for example, Baxter and King (1993), Sims (1998), and Leeper and Yang (2008)].

We estimate four versions of the model: all four fiscal instruments - government spending, lump-sum transfers, and capital and labor taxes - adjust to stabilize debt; only capital and labor taxes adjust; only government spending adjusts; only lump-sum transfers adjust.

\footnotetext{
${ }^{1}$ Theoretical examples include Ricardian equivalence [Barro (1974)], "unpleasant monetarist arithmetic" [Sargent and Wallace (1981)], and the fiscal theory of the price level [Leeper (1991), Sims (1994), Woodford (1995), and Cochrane (1999)].

${ }^{2}$ Though see Favero and Giavazzi (2007) for a study that examines how including debt affects inferences from a VAR.
} 
Model specification tests imply that U.S. time series strongly prefer the more complex model in which all four instruments stabilize debt.

The paper reports present-value multipliers for each of the fiscal instruments and shows that they can differ dramatically across the various model specifications. Because inferences about policy effects depend strongly on the underlying fiscal rules, the finding underscores the importance of modeling fiscal financing dynamics. Moreover, these dynamics can be quite long lasting - its takes 20 to 25 years to restore intertemporal fiscal balance after shocks to capital taxes, consumption taxes, or transfers; it can take 40 years or more to restore balance after labor tax or government spending shocks. Because of these low-frequency dynamics, short-run and long-run multipliers can differ markedly.

With estimates of the model's "deep parameters" in hand, it is possible to conduct counterfactual experiments that alter policy rules, holding private parameters fixed at their estimated values. We address three counterfactual questions: (1) How do the impacts of fiscal shocks change if future policies respond to debt more or less gradually than they have historically? (2) How do fiscal multipliers change when, instead of the historical sources of financing for debt, we imagine that only future capital taxes adjust? (3) What are the longrun consequences of enhanced "automatic stabilizers?" Answers to questions like these can help guide policy choices.

This paper complements a large-scale global modeling effort underway at the International Monetary Fund to estimate DSGE models that incorporate fiscal policy rules that allow for both distortionary and non-distortionary sources of fiscal financing by focusing on simpler models that are more easily interpretable and emphasizing fresh implications that spring from explicit modeling of government debt dynamics. ${ }^{3}$

Our results are subject to an important caveat: they do not include the interactions between monetary and fiscal policies that tend to arise in practice, and certainly occurred in response to the recent recession. Recent work finds that fiscal multipliers can change dramatically when monetary policy is passive, failing to satisfy the Taylor principle, or when the central bank's interest rate instrument is at or near the zero lower bound [for example, Christiano, Eichenbaum, and Rebelo (2009), Cogan, Cwik, Taylor, and Wieland (2009), Davig and Leeper (2009), or Eggertsson (2009)]. On the other hand, by abstracting from nominal considerations, this paper puts empirical flesh on the multipliers that Uhlig (2009) calculates in a calibrated model.

This paper is organized as follows. Section 2 describes the estimated model, our assumptions regarding fiscal policies, and the technique used to solve the model. Section 3 outlines the techniques we use to estimate the model, and our assumptions regarding prior

\footnotetext{
${ }^{3}$ Some example of papers flowing from the IMF effort include Laxton and Pesenti (2003), Botman, Laxton, Muir, and Romanov (2006), and Kumhof and Laxton (2008a,b).
} 
distributions. Section 4 summarizes the estimation results while section 5 reports some counterfactual exercises. Section 6 concludes.

\section{The Models}

The model economy is a neoclassical growth model extended to include intertemporal investment adjustment costs, variable capacity utilization, and external habit formation. The economy consists of a representative household, a representative firm, and the government. There are nine transitory shocks in the economy, denoted by $u_{t}$ 's, including two preference shocks, an investment-specific shock, neutral technology shock, and shocks to fiscal instruments.

2.1. Households. The representative household derives utility from consumption, $c_{t}$, relative to a habit stock. We assume that the habit stock is given by a fraction of aggregate consumption from the previous period $h C_{t-1}$ where $h \in[0,1]$. The household derives disutility from hours worked, $l_{t}$. In addition, there is a general preference shock, $u_{t}^{b}$, that affects the household's intertemporal substitution and a preference shock specific to labor supply $u_{t}^{l}$. Specifically, the household maximizes the intertemporal utility function

$$
E_{t} \sum_{t=0}^{\infty} \beta^{t} u_{t}^{b}\left[\frac{1}{1-\gamma}\left(c_{t}-h C_{t-1}\right)^{1-\gamma}-u_{t}^{l} \frac{l_{t}^{1+\kappa}}{1+\kappa}\right]
$$

where $\gamma, \kappa \geq 0$ and $\beta \in(0,1)$. The shocks $u_{t}^{b}$ and $u_{t}^{l}$ follow $\operatorname{AR}(1)$ processes given by

$$
\begin{aligned}
& \ln \left(u_{t}^{b}\right)=\left(1-\rho^{b}\right) \ln \left(u^{b}\right)+\rho^{b} \ln \left(u_{t-1}^{b}\right)+\sigma_{b} \epsilon_{t}^{b}, \quad \epsilon_{t}^{b} \sim N(0,1) \\
& \ln \left(u_{t}^{l}\right)=\left(1-\rho^{l}\right) \ln \left(u^{l}\right)+\rho^{l} \ln \left(u_{t-1}^{l}\right)+\sigma_{l} \epsilon_{t}^{l}, \quad \epsilon_{t}^{l} \sim N(0,1)
\end{aligned}
$$

The household's flow budget constraint is given by

$$
\left(1+\tau_{t}^{c}\right) c_{t}+i_{t}+b_{t}=\left(1-\tau_{t}^{l}\right) w_{t} l_{t}+\left(1-\tau_{t}^{k}\right) R_{t}^{k} v_{t} k_{t-1}+R_{t-1} b_{t-1}+z_{t}
$$

Total income and wealth consists of labor income, capital income, lump-sum transfers from the government, $z_{t}$, and interest bearing government bonds. These assets can be used for consumption, investment in physical capital $i_{t}$, and for purchasing more government bonds. Capital income is given by the return on the effective amount of capital services supplied to firms in period $t, v_{t} k_{t-1}$, where $v_{t}$ measures capacity utilization in period $t$. One-period government debt outstanding at time $t, b_{t}$, pays a gross interest rate of $R_{t} . \tau_{t}^{c}, \tau_{t}^{l}$, and $\tau_{t}^{k}$ are tax rates on consumption, labor income, and capital income.

The law of motion for capital is given by

$$
k_{t}=\left(1-\delta\left(v_{t}\right)\right) k_{t-1}+\left[1-s\left(\frac{u_{t}^{i} i_{t}}{i_{t-1}}\right)\right] i_{t}
$$


Following Smets and Wouters (2003) and Christiano, Eichenbaum, and Evans (2005), $s\left(\frac{u_{t}^{i} i_{t}}{i_{t-1}}\right) i_{t}$ is a cost of adjustment incurred if the household varies its investment level from the level in the previous period. The function $s(\cdot)$ has the following properties at steady state: $s(1)=s^{\prime}(1)=0$ and $s^{\prime \prime}(1)>0$. In addition, the adjustment cost is subject to a specific efficiency shock $u_{t}^{i}$ which follows the $\mathrm{AR}(1)$ process

$$
\ln \left(u_{t}^{i}\right)=\left(1-\rho^{i}\right) \ln \left(u_{t}^{i}\right)+\rho^{i} \ln \left(u_{t-1}^{i}\right)+\sigma_{i} \epsilon_{t}^{i}, \quad \epsilon_{t}^{i} \sim N(0,1)
$$

Owners of physical capital can control the intensity with which the capital stock is utilized. We assume that increasing the intensity of capital utilization entails a cost in the form of a faster rate of depreciation. Following Schmitt-Grohe and Uribe (2008), we adopt a quadratic form for the function $\delta$ :

$$
\delta\left(v_{t}\right)=\delta_{0}+\delta_{1}\left(v_{t}-1\right)+\frac{\delta_{2}}{2}\left(v_{t}-1\right)^{2}
$$

The household maximizes utility subject to its budget constraint, (3), and the law of motion for capital, characterized by (4) and (6).

2.1.1. Firms. The representative firm rents capital and labor from the household to maximize profit given by

$$
u_{t}^{a} k_{t-1}^{\alpha} l_{t}^{1-\alpha}-w_{t} l_{t}-R_{t}^{k} v_{t} k_{t-1}
$$

where $\alpha \in[0,1]$ and $u_{t}^{a}$ denotes a neutral technology shock that is assumed to follow the $\operatorname{AR}(1)$ process

$$
\ln \left(u_{t}^{a}\right)=\left(1-\rho^{a}\right) \ln \left(u^{a}\right)+\rho^{a} \ln \left(u_{t-1}^{a}\right)+\sigma_{a} \epsilon_{t}^{a}, \quad \epsilon_{t}^{a} \sim N(0,1)
$$

Total output at period $t$ is given by $y_{t}=u_{t}^{a} k_{t-1}^{\alpha} l_{t}^{1-\alpha}$. From the solution to the firm's problem, wages and capital rental are given by

$$
w_{t}=\frac{(1-\alpha) y_{t}}{l_{t}}, \quad R_{t}^{k} v_{t}=\frac{\alpha y_{t}}{k_{t-1}}
$$

2.1.2. Fiscal Policy. The government budget constraint is

$$
B_{t}+\tau_{t}^{k} R_{t}^{k} v_{t} k_{t-1}+\tau_{t}^{l} w_{t} L_{t}+\tau_{t}^{c} C_{t}=R_{t-1} B_{t-1}+G_{t}+Z_{t}
$$

where $G_{t}$ is government expenditure and $X_{t}$ represents the aggregate level of any variable $x$. Fiscal policy follows rules that embed three features. First, there may be some "automatic stabilizer" component to movements in fiscal variables. This is modeled as a contemporaneous response to deviations of output from steady state. Second, all instruments except consumption taxes are permitted to respond to the state of government debt. Third, since fiscal policy makers often consider changes in tax rates jointly, we allow shocks affecting one 
tax rate to also affect other tax rates contemporaneously. In terms of log deviations from steady state, the policy rules are:

$$
\begin{aligned}
\hat{G}_{t} & =-\varphi_{g} \hat{Y}_{t}-\gamma_{g} \hat{B}_{t-1}+u_{t}^{g}, \quad u_{t}^{g}=\rho_{g} u_{t-1}^{g}+\sigma_{g} \epsilon_{t}^{g}, \\
\hat{\tau}_{t}^{k} & =\varphi_{k} \hat{Y}_{t}+\gamma_{k} \hat{B}_{t-1}+\phi_{k l} u_{t}^{l}+\phi_{k c} u_{t}^{c}+u_{t}^{k}, \quad u_{t}^{k}=\rho_{k} u_{t-1}^{k}+\sigma_{k} \epsilon_{t}^{k}, \\
\hat{\tau}_{t}^{l} & =\varphi_{l} \hat{Y}_{t}+\gamma_{l} \hat{B}_{t-1}+\phi_{l k} u_{t}^{k}+\phi_{l c} u_{t}^{c}+u_{t}^{l}, \quad u_{t}^{l}=\rho_{l} u_{t-1}^{l}+\sigma_{l} \epsilon_{t}^{l}, \\
\hat{\tau}_{t}^{c} & =\phi_{k c} u_{t}^{k}+\phi_{l c} u_{t}^{l}+u_{t}^{c}, \quad u_{t}^{c}=\rho_{c} u_{t-1}^{c}+\sigma_{c} \epsilon_{t}^{c}, \\
\hat{Z}_{t} & =-\varphi_{Z} \hat{Y}_{t}-\gamma_{Z} \hat{B}_{t-1}+u_{t}^{z}, \quad u_{t}^{z}=\rho_{Z} u_{t-1}^{z}+\sigma_{Z} \epsilon_{t}^{z},
\end{aligned}
$$

where hats denote log-deviations of variables and each of the $\epsilon$ 's is distributed $N(0,1)$.

Consumption taxes are taken follow an exogenous process because U.S. federal consumption taxes are mostly excise taxes on specific goods (gasoline, tobacco, etc.) and are used mainly for special funds. Thus, they do not adjust to changes in current output or government debt.

The other fiscal instruments follow rules that allow response to the cyclical position of the economy $\left(\varphi_{i} \geq 0\right.$ for $\left.i=\{g, k, l, z\}\right)$ and to changes in the level of government debt $\left(\gamma_{i} \geq 0\right.$ for $i=\{g, k, l, z\})$. To capture the persistent nature of exogenous changes in instruments, we allow the shocks to be serially correlated $\left(\rho_{i} \in[0,1]\right.$ for $\left.i=\{g, k, l, z\}\right)$. In addition we augment the fiscal rules with $i . i . d$. error terms $\left(\epsilon_{t}^{i}\right.$ for $\left.i=\{g, k, l, z\}\right)$ to capture unexpected changes in policy. Parameters $\phi_{i j}$ for $i, j=\{k, l, c\}$ controls how much unpredicted movement in one tax rate is due to an exogenous shock to another tax rate.

2.2. Market Equilibrium and Model Solution. The final goods market is in equilibrium if aggregate production equals aggregate demand for consumption and investment by the household and government

$$
Y_{t}=C_{t}+I_{t}+G_{t}
$$

The capital rental market and labor market are in equilibrium if both the first-order conditions for the household and the firm are satisfied. In addition, any equilibrium must satisfy the transversality conditions for debt and capital accumulation. Note that equilibrium implies $x_{t}=X_{t}$ for any variable $x$.

Equilibrium conditions and their log-linearizations around the deterministic steady state are given in appendix A. The log-linearized model is solved using Sims's (2001) gensys algorithm. The solution is of the form:

$$
\mathbf{x}_{t}=G(\Theta) \mathbf{x}_{t-1}+M(\Theta) \epsilon_{t}, \quad \epsilon_{t} \sim N(\mathbf{0}, \mathrm{I})
$$

where $\Theta$ denotes the vector of structural parameters to be estimated and $\mathbf{x}_{t}$ denotes the vector of model variables at time $t$. 


\section{Estimation}

We report results from estimates of four models that differ in which fiscal instruments are permitted to respond to debt: four fiscal instruments - government spending, lump-sum transfers, and capital and labor taxes - adjust; only capital and labor taxes adjust; only government spending adjusts; only lump-sum transfers adjust.

Models are estimated with U.S. quarterly data from 1960Q1 to 2008Q1. We use nine time series: real consumption, real investment, hours worked, real government debt, real government spending, real capital tax revenues, real labor tax revenues, real consumption tax revenues, and real government transfers. Appendix B describes the data construction. We detrend the logarithm of each variable with a linear trend. Let $\mathbf{y}_{t}$ denote the vector of observables and define the following measurement equation relating observables to model variables

$$
\mathbf{y}_{t}=H \mathbf{x}_{t}
$$

Using this mapping between observables and model variables, we estimate the model using Bayesian methods. First, we use Chris Sims's optimization routine csminwel to maximize the log posterior function, which combines the priors and the likelihood of the data. Then we use the random walk Metropolis-Hastings algorithm to sample from the posterior distribution. ${ }^{4}$ When performing the optimization routine, we initialize the posterior mode search with parameter values drawn at random from the prior densities. We perform several - at least 50 - searches for the mode from different starting values to determine if more than one mode exists. In all the models, the searches for the posterior mode almost always converged to the same parameter values and likelihood value. ${ }^{5}$ After running the $\mathrm{MH}$ algorithm, we perform diagnostics to ensure convergence of the MCMC chain. ${ }^{6}$

3.1. Priors and Calibrated Values. Table 1 presents the values assigned to the calibrated parameters (which can be viewed as very strict priors). These values were kept fixed because our data set is demeaned and cannot pin down many steady state values in the estimation procedure. The discount factor, $\beta$, is set to equal 0.99 , which implies an annual steady state

\footnotetext{
${ }^{4}$ A sample of 5,000,000 draws was created with the first 250,000 used as a burn-in period and every 200th thinned. The posterior mode and the inverse Hessian at the posterior mode resulting from the optimization procedure were used to define the transition probability function. A step size of 0.3 resulted in acceptance rates between 34 percent and 38 percent.

${ }^{5}$ The few exceptions were simply cases where the numerical optimization procedure failed to converge to any value. In addition, since we initialize the $\mathrm{MH}$ algorithm with the posterior mode and Hessian, we checked the gradient and the conditioning number of the Hessian at the mode and plotted slices of the likelihood around the mode. These details appear in an estimation appendix available upon request.

${ }^{6}$ Diagnostics include trace plots, verifying the chain is well mixed (i.e. has low serial correlations in sample draws), and performing Geweke's (2005, pp. 149-150) Separated Partial Means tests. All results appear in an estimation appendix available upon request.
} 
interest rate of 4 percent. We set $\alpha$ equal to 0.3 , which implies a labor share of 70 percent. We assume that the annual steady state depreciation rate is 10 percent, which implies that $\delta_{0}$ equals 0.025 . We calibrate the parameter $\delta_{1}$ to ensure that capacity utilization, $v$, equals unity in the steady state. In addition, the steady state tax rates and the ratios of government spending and debt to output are set equal to the mean values of our data set.

Tables 2 and 3 shows the prior distributions for the remaining parameters, and figures 1 and 2 plot the probability density functions that correspond to these priors. We assume that the parameters are independent a priori. The priors are similar to those commonly used in the literature [see Smets and Wouters (2003), Forni, Monteforte, and Sessa (2009), and An and Schorfheide (2007) for examples]. The means were set at values that correspond with estimates of other studies in the literature and the standard errors were set so that the domain covers a reasonable range of parameter values, including values estimated by previous studies.

For the preference parameters, a Gamma distribution is assumed for the coefficients of risk aversion $\gamma$ and of Frisch elasticity $\kappa$, with means of 1.75 and 2, respectively, and a standard deviation for both parameters equal to 0.5 , so that both prior masses are concentrated on values higher than a logarithmic specification. The habit coefficient $h$, whose mean is set at 0.5 , is distributed according to a Beta distribution with a standard deviation of 0.2 . The capital utilization adjustment coefficient $\delta_{2}$, whose means is set at 0.7 , is distributed according to a Gamma distributions with standard deviations of 0.5. This gives the prior density the most mass at values that are less than one, which is consistent with the estimates of Schmitt-Grohe and Uribe (2008). Beta distributions are chosen for the autoregressive coefficients (all $\rho_{j}$ 's) as well, with means and standard deviations set at 0.7 and 0.2 , respectively. The standard deviations of the innovations are assumed to be distributed as Inverse Gamma. The investment adjustment coefficient, $s^{\prime \prime}$, has a Gamma distribution with a mean of 5 and standard deviation equal to $0.25 .^{7}$

The priors for the fiscal parameters were chosen to be fairly diffuse and cover a reasonably large range of parameter values. The fiscal responses to government debt (the $\gamma_{i}$ 's) are assumed to have a Gamma distribution with a mean of 0.4 and standard deviation of 0.2 (so that they will range approximately between 0 and 1.25). The fiscal instruments' elasticities with respect to output (the $\varphi_{i}$ 's) are assumed to have Gamma distributions. The mean of the government spending elasticity is 0.07 and its standard deviation is 0.05 while the mean of the transfer elasticity is 0.2 and its standard deviation is 0.1 . These values ensure the

\footnotetext{
${ }^{7}$ Prior to estimation, we performed an analysis similar to An and Schorfheide (2007) to investigate the identifiability of parameters. We randomly drew several sets of parameter values from the prior distributions, simulated data, and investigated the ability to recover the underlying parameters using our estimation strategy. Results (available from the authors upon request) suggest that the Frisch elasticity parameter, $\kappa$ is not well identified. In addition, $\gamma, \kappa$, and $s^{\prime \prime}$ seem to be correlated. Our tight prior on $s^{\prime \prime}$ is a reflection of its weak identifiability.
} 
domains cover the range of values estimated by past research [see Blanchard and Perotti (2002), Giorno, Richardson, Roseveare, and van den Noord (1995), and Yang (2005) for examples]. Blanchard and Perotti's (2002) estimates of the elasticity of tax revenue with respect to output inform the priors over $\varphi_{k}$ and $\varphi_{l}$. They report that a 1 percent increase in output leads to a 2.08 percent increase in tax revenue based on 1947:1-1997:4 U.S. data, which implies roughly a 1 percent increase in the average tax rate. Since we incorporate Social Security taxes in our labor tax revenue data, the labor tax rate elasticity is expected to be a value below this average because Social Security taxes are capped and are regressive. Thus, we set the labor tax rate elasticity to have a mean and standard deviation of 0.5 and 0.25 , and the capital tax rate elasticity to have a mean and standard deviation of 1 and 0.3 .

The parameter measuring the co-movement between the capital and labor tax rate shocks $\left(\phi_{k l}\right)$ is assumed to have a Normal distribution with a mean of 0.25 and a standard deviation of 0.1 . Yang (2005) estimates $\phi_{k l}$ to be 0.26 . The parameters measuring the co-movement between the capital and consumption tax rate shocks and between the labor and consumption tax rate shocks $\left(\phi_{k c}\right.$ and $\left.\phi_{l c}\right)$ are assumed to have a Normal distribution with a mean of 0.05 and a standard deviation of 0.1 . To our knowledge, there is no past research estimating $\phi_{k c}$ and $\phi_{l c}$. Given that consumption taxes in our U.S. data set are mainly excise taxes used for special funds, we do not expect these values to be large.

\section{Estimation Results}

Tables 2-3 report the means and 5 and 95 percentiles of the posterior distribution for each of the four models estimated. With the exception of the comovement terms between consumption and labor/capital taxes, all parameters are estimated to be away from zero. Interestingly, the non-policy parameter estimates are about the same across the various model specifications and are similar to estimates in the literature. With the exception of the investment specific shock and preference shock, all the persistent shocks are estimated to have an autoregressive parameter which is higher than the mean of 0.7 assumed in the prior distribution. Our estimate of the intertemporal elasticity of substitution $(1 / \gamma)$ is less than one, and the external habit stock is estimated to be about 50 percent of past consumption. ${ }^{8}$ The estimate of the Frisch elasticity $\kappa$ is around 2.

Turning to the policy parameter estimates, the results indicate that several distortionary fiscal instruments have played an important role in financing debt innovations. Although the response of lump-sum transfers to debt innovations is the highest, the responses of capital tax rates and government spending are also important. In contrast, it appears that labor

\footnotetext{
${ }^{8}$ The results suggest the posterior of habit is quite similar to its prior. However, we estimated a different version of the model where we changed the prior on habit formation to be a beta distribution with a mean of 0.7 and standard deviation of 0.2 , and in this case, the posterior estimates of the habit stock were almost identical to the ones reported here (estimates in an additional estimation appendix available upon request).
} 
taxes have not responded strongly to debt. The results also show that capital tax rates have had a highly procyclical response to the level of aggregate output, while labor tax rates are less responsive. Transfers have responded to the level of aggregate output, but the estimate here is slightly smaller than that used in previous studies; Perotti (2004), for example, uses a value of -0.15 in his VAR estimation strategy. Finally, we find that exogenous changes to capital and labor tax rates affect the two rates simultaneously $\left(\phi_{k l} \in[0.1, .25]\right)$, suggesting that typical tax legislation tends to change both tax rates. In contrast, exogenous changes to consumption tax rates do not affect the capital or labor tax rates.

4.1. Impulse Responses. Figures 3-7 plot the impulse responses following a temporary 1 percent exogenous increase in each fiscal instrument. The solid line is generated with the mean estimates of the posterior distribution, while the dashed lines give the 5th and 95th percentiles based on the posterior distributions. Each row compares the responses of a variable across the various estimated models, while each column reports responses within a model. The last column shows the fiscal impacts of the best fitting model where all fiscal instruments respond to debt.

Figure 3 illustrates the responses of output, consumption, investment, and government debt following a 1 percent shock to government spending. As is standard in a RBC-style model, an increase in government spending reduces wealth, increasing work effort and output on impact. Government spending crowds out investment and its negative wealth effect leads consumption to decline. However, these effects can be quickly reversed depending on how the government debt is financed. For instance, when only capital and labor taxes are expected to increase in the future to support the expansion in debt, the return on future capital and labor is lowered (second column). Households cut back on investment and hours worked, causing output to fall below its initial steady state level within two years of the initial fiscal expansion; output remains well below its steady state level for over 10 years. A similar result also occurs in Forni, Monteforte, and Sessa (2009), which also allows only distortionary taxes to respond to debt innovations in a new Keynesian model. In contrast, when lumpsum transfers or a combination of all the fiscal instruments are allowed to respond to debt innovations, output remains above its steady state level throughout its transition period (first and fourth columns). ${ }^{9}$

Impacts of a 1 percent increase in the capital tax rate appear in figure 4. Standard theory suggests that when capital taxes increase, investment, labor, and output decrease immediately while consumption rises as agents sacrifice investment for consumption [see Baxter and King (1993), Braun (1994) and Leeper and Yang (2008)]. In the estimated models, the responses of variables can differ dramatically from these conventional effects.

\footnotetext{
${ }^{9}$ This result is, in part, model specific and might not hold if transfers were distortionary. However, the results suggest that which combination of fiscal instruments responds to debt is central for the paths of aggregate variables. Even under alternative model specifications, this general feature will hold.
} 
For instance, for all four models considered, consumption decreases on impact following a capital tax increase. This reduction occurs because exogenous changes to capital and labor taxes are correlated; when capital taxes increase, labor taxes increase as well, which causes households to work and consume less.

The path of investment also differs qualitatively depending on which fiscal instruments respond to debt. If capital and labor taxes are expected to decrease in order to offset the reduction in debt, investment rises above its steady state level and remains positive throughout the transition path (second column). The increase in investment and hours worked (not pictured), increase output above its steady state level. In this case the capital tax rate (not pictured) actually drops below its original steady state level after approximately three years before it returns to its steady state. The resulting increase in tax revenues is more than enough to offset the change in debt, allowing the capital tax rate to fall and further spur investment and output.

Figure 5 reports the effects of a 1 percent increase in the labor tax rate. In all cases, the responses of output and consumption are conventional: higher labor taxes lead households to reduce their labor supply, reducing disposable income and consumption. Reduction in labor supply lowers output. On impact, one might expect investment to decline as well, since the return to capital falls as households decrease their labor supply. However, the impulse responses demonstrate that this prediction depends crucially on which fiscal instruments adjust to debt innovations. In fact, all three models that allow distortionary fiscal instruments to adjust to debt do not rule out the possibility of investment increasing on impact (since a positive response is within the probability bands of the impulse responses). When taxes adjust to debt, investment increases with the mean response peaking at 1 percent above steady state (second column). In this case, capital taxes actually decrease on impact. This decrease is brought about by the capital tax rate response to output, which declines on impact. Capital taxes then continue to be consistent with declining debt, increasing the return to investment.

Effects of higher consumption taxes, shown in figure 6, are similar. They tend to lower consumption, but raise investment. When distorting instruments stabilize debt, output rises within a couple of years. Output falls when transfers alone adjust to debt.

Figure 7 illustrates the responses to a 1 percent increase in lump-sum transfers. Because lump-sum transfers are non-distortionary in our model, the responses of output, consumption, and investment are driven entirely by agents' expectations of how the resulting increase in debt will be financed. For instance, if government spending decreases to finance the higher debt, investment falls for about 5 years before rising (third column); when taxes are expected to rise, investment falls markedly over the entire forecast horizon (second column). 
4.2. Posterior Odds Comparisons. The results of the previous section suggest that assumptions about which fiscal instruments adjust to debt innovations play critical roles in determining the transition paths of variables in response to fiscal shocks. Which scenarios are favored by the data? We use Bayes factors to evaluate the relative model fit, calculating the log-marginal data density using Geweke's (1999) modified harmonic mean estimator, as outlined in An and Schorfheide (2007). As explained by Fernandez-Villaverde and RubioRamirez (2004), the Bayes factor is the ratio of the probabilities from having observed the data given each model, as reflected by the marginal data densities. The Bayes factor is a measure of the evidence provided by the data in favor of one model over another.

Table 4 displays the log-marginal data density and Bayes factor for the four models already discussed plus a fifth model in which only transfers respond to debt and the countercyclical parts of policy, as well as the correlation among shocks to tax rates, are shut down (labeled Addendum in the table). The results suggest that the models with a response of transfers to changes in debt $\left(\gamma_{z}>0\right)$ fit better than the models without the transfer-debt response. ${ }^{10}$ Richer models that include more complex fiscal adjustment perform better than the simpler models, even though the Bayes factor discriminates against complex models with more parameters. This can be seen by comparing the fit of the model where transfers adjust with and without the output responses and tax comovement terms, the last model whose Bayes factor is listed in the table.

The log marginal likelihood difference between the model where only lump-sum transfers adjust to debt and the model that allows all fiscal variables to respond to debt is 7 . This number can be interpreted as reporting that to prefer the model in which only transfers adjust, one would need to have a prior probability for the transfers-only model that is 1,097 $(=\exp [7])$ times larger than our prior over the model in which all instruments adjust. The common theoretical practice of ignoring debt financing by assuming that lump-sum transfers clear the government budget is not favored by the data. The results also suggest that we would need a prior probability for the model in which only taxes adjust that is $148(=\exp [5])$ times larger than our prior over the model in which only government spending adjusts. In fact, the model allowing only taxes to adjust to debt seems to be the least favored by the data. Similar studies that estimate fiscal policy rules allow either only lump-sum transfers or only distortionary taxes to adjust to debt [for example, Forni, Monteforte, and Sessa (2009), Kamps (2007), Ratto, Roeger, and in't Veld (2006), and Coenen and Straub (2004)]. The comparisons here suggest that the data prefer specifications that allow lump-sum transfers, distortionary taxes, and government spending to adjust.

Fit deteriorates sharply when only transfers adjust but countercyclical aspects of policy behavior and correlation among tax shocks are eliminated (Addendum in table 4). This

\footnotetext{
${ }^{10}$ In the present model, transfers are lump-sum. This finding could change if transfers were not neutral.
} 
specification essentially treats government spending and tax rates as exogenous processes, a practice that is common when generating theoretical predictions about fiscal impacts.

4.3. Present-Value Multipliers. Quantitative effects of fiscal shocks are frequently summarized by fiscal multipliers for output, consumption, and investment. Following Mountford and Uhlig (2009), we report present-value multipliers, which are preferred over impact multipliers because they embody the full dynamics associated with fiscal disturbances and they properly discount macroeconomic effects in the future. The present value of additional output over a $k$-period horizon that is generated by a change in the present value of government spending is calculated as

$$
\text { Present-Value Multiplier }(k)=\frac{E_{t} \sum_{j=0}^{k}\left(\prod_{i=0}^{j} R_{t+i}^{-1}\right) \Delta Y_{t+j}}{E_{t} \sum_{j=0}^{k}\left(\prod_{i=0}^{j} R_{t+i}^{-1}\right) \Delta G_{t+j}}
$$

Tables 5 and 6 report the results. Note that the present-value multiplier at $k=1$ is equal to the impact multiplier at period one; impact multipliers are widely reported in empirical studies [for example, Blanchard and Perotti (2002), Forni, Monteforte, and Sessa (2009)].

When all fiscal instruments respond to debt, as in table 5, present-value multipliers tend to be modest; no multiplier exceeds 1 . Government spending multipliers for output are substantially lower that those obtained in loosely identified empirical studies, which frequently are around 1.5 [Blanchard and Perotti (2002), Monacelli and Perotti (2008), Romer and Bernstein (2009)], but are comparable to those from real business cycle models [Uhlig (2009)]. ${ }^{11}$ Spending multipliers for consumption are uniformly negative, a result that is standard in real models, but has recently received much attention [Gali, Lopez-Salido, and Valles (2007), Ravn, Schmitt-Grohe, and Uribe (2007), Monacelli and Perotti (2008), Davig and Leeper (2009)]. In contrast to Uhlig's (2009) calibrated results, we find that in the best fitting model there is no tendency for tax multipliers to be larger than spending multipliers, except that in our estimates, higher transfers reduce output.

Present-value multipliers change dramatically when only capital and labor taxes react to stabilize debt, as table 6 reports. First, it is commonplace for long-run multipliers to have a different sign from short-run multipliers [see also Judd (1985), Sims (1998), Leeper and Yang (2008), Uhlig (2009)]. Higher government spending stimulates output for a couple of years, but as taxes rise, output falls and the long-run present-value multiplier is sharply negative. Lower capital taxes only weakly raise output in the short run; after a couple of years output reverses and is below steady state until eventually returning back to steady state. Because there is a brief time (25 quarters in the table) where output has already

\footnotetext{
${ }^{11}$ As noted in the introduction, the introduction of nominal considerations, including nominal rigidities, and monetary policy behavior can change the size of multiplier dramatically [Christiano, Eichenbaum, and Rebelo (2009), Cogan, Cwik, Taylor, and Wieland (2009), Davig and Leeper (2009), or Eggertsson (2009)].
} 
increased above steady state and capital tax revenue are still above steady state, multiplier is positive. Eventually, though, capital taxes must adjust to the lower level of debt and drop below steady state. At this point, capital tax revenues drop below steady state and the very long run the present value multiplier is strongly negative. Second, as the output multiplier of -3.70 demonstrates (second panel of table 6), capital tax multipliers can be very large indeed in the long run. ${ }^{12}$

4.4. Present-Value Financing. We turn now to the forward-looking aspect of government finance. We calculate the present-value decompositions of debt to calculate what combination of adjustments in the expected paths of fiscal policy instruments and discount rates rationalize the observed value of government debt. We also examine how adjustments depend on the nature of the fiscal policy shock. In log-linearized form, the government's present-value relation is

$\hat{B}_{t}=E_{t} \sum_{j=1}^{\infty} \beta^{j}\left[\left(\frac{T^{k}}{B}\right) \hat{T}_{t+j}^{k}+\left(\frac{T^{l}}{B}\right) \hat{T}_{t+j}^{l}+\left(\frac{T^{c}}{B}\right) \hat{T}_{t+j}^{c}-\left(\frac{G}{B}\right) \hat{G}_{t+j}-\left(\frac{Z}{B}\right) \hat{Z}_{t+j}-\frac{1}{\beta} \hat{R}_{t+j-1}\right]$

where the unsubscripted variables denote steady state values and $\hat{T}_{t+j}^{k}, \hat{T}_{t+j}^{l}$, and $\hat{T}_{t+j}^{c}$ denote total revenues due to capital, labor, and consumption taxes. This expression decomposes fluctuations in real debt into expected changes in the components of net-of-interest surpluses, at constant discount rates, and expected changes in real discount rates.

The present-value decompositions for the best fitting model, in which all fiscal instruments adjust to stabilize debt, are listed in table 7 . The table shows each of the present-value components in (19) following a shock to each of the exogenous processes when the shock is calibrated to raise or lower debt by one unit of the final good. Different shocks are financed very differently in present-value terms. When the components have the same sign as the change in debt, the component is expected to move to support the change in debt; when the signs differ, the component is expected to move against stabilizing debt.

For the capital and labor tax shocks, both the discount rate and the present value of surpluses move to support debt. With a capital tax shock, most of the work is done by changes in the present value of surpluses, whereas for labor taxes, the discount rate contributes more. In contrast, following a shock to government spending, the present value of surpluses alone moves to support debt, with taxes, spending, and transfers changes offsetting each other. The discount rate, on the other hand, resists present-value balance. Similar results hold for a technology, general preference, or labor preference shock. Following a shock to

\footnotetext{
${ }^{12}$ Variance decompositions suggest that fiscal policy shocks contribute little to the cyclical variability of aggregate non-policy variables, but fiscal variables are affected by all policy and non-policy shocks, reflecting the influence of each fiscal instruments' response to output and debt. Forni, Monteforte, and Sessa (2009) obtain similar results.
} 
transfers, most of the present-value balancing is done by surpluses. While the same is true for consumption tax shocks, the discount rate tends to move against present-value balance. Interestingly, an investment-specific shock generates movements in the discount rate that support debt, while the surplus resists present-value balance.

For each type of shock, taxes, spending, and transfers experience sizeable but offsetting movements in present value. Interestingly, none of the fiscal policy instruments consistently move to support the innovation in debt in all cases. All instruments can move to support or offset debt innovations, depending on the shock.

Figure 8 displays the present-value funding horizons of government debt innovations for various fiscal shocks using the best fitting model in which all fiscal instruments respond to debt. The figure can answer the question, "What fraction on a 1-unit innovation in government debt in quarter $t$, due to each of the five fiscal shocks, is financed by period $t+K$, where $K$ is determined by the quarters on the $x$-axis?" The figure, therefore, reports the truncated sum over horizon $K$, denoted by $P V_{t}(K)$, and defined by

$$
P V_{t}(K)=E_{t} \sum_{j=1}^{K} \beta^{j}\left[\left(\frac{S}{B}\right) \hat{S}_{t+j}-\left(\frac{1}{\beta}\right) \hat{R}_{t+j-1}\right]
$$

where $S$ is the steady state net-of-interest surplus and $\hat{S}_{t+j}$ denotes percentage deviations of the surplus from steady state.

As the figure makes clear, it takes many years for fiscal adjustments to restore presentvalue balance. Debt innovations induced by consumption taxes, capital taxes, or transfers are fully financed after 20 to 25 years. Government spending and labor tax shocks, however, can take 40 or more years to be fully financed. Over shorter horizons up to two years, serial correlation in the shocked policy instrument worsens the fiscal stance in the sense that the sum in (20), truncated at $K \leq 8$, moves farther from the value of $\hat{B}_{t}$.

4.5. Sensitivity Analysis: Subsample Estimates. This section examines posterior mode estimates for various sub-samples in order to investigate the stability of the full sample estimates. The first subsample, 1976Q1-2008Q1, eliminates the 1973-75 recession from the sample as well as the Tax Reduction Act of 1975 passed to provide a one-time tax rebate to stimulate the economy. The second subsample, 1989Q1-2008Q1, ignores the initial effects of the Tax Reform Act of 1986, which changed the structure of income and corporate income tax rates. Finally, the last subsample, 1993Q1-2008Q1, starts after the recession of 1990Q3-91Q1 and begins with the implementation of the Omnibus Budget Reconciliation Act of 1993. Table 8 compares the modes of the posterior distributions over these periods.

The estimates of the structural parameters vary slightly across the subsamples. The results are consistent with Smets and Wouters (2007) in that habit formation seems to 
increase in the later subsamples and the capacity utilization parameter increases over the 1989Q1-2008Q1 subsample. ${ }^{13}$ The most significant differences between the three subsamples are the coefficients for the fiscal instruments' responses to debt. Labor tax rates responded more strongly to debt, while transfers responded less strongly over the subsamples. The results suggest that in the last fifteen years capital taxes have had the strongest response to debt.

\section{Counterfactual Fiscal Experiments}

Given estimates of the model's "deep parameters," we can consider counterfactual questions that ask how fiscal impacts might change under policies that are different from history. All three sets of counterfactuals use the private parameters from the best fitting model in which all instruments respond to debt and then intervene in various ways on the policy rules.

5.1. Speed of Fiscal Adjustments. We consider alternative scenarios in which we scale all fiscal adjustment parameters up or down to increase or decrease the speed of adjustment of future policies to government debt. Fiscal policy rules become

$$
\begin{aligned}
\hat{G}_{t} & =-\varphi_{g} \hat{Y}_{t}-\mu \gamma_{g} \hat{B}_{t-1}+u_{t}^{g}, \\
\hat{\tau}_{t}^{k} & =\varphi_{k} \hat{Y}_{t}+\mu \gamma_{k} \hat{B}_{t-1}+\phi_{k l} u_{t}^{l}+\phi_{k c} u_{t}^{c}+u_{t}^{k} \\
\hat{\tau}_{t}^{l} & =\varphi_{l} \hat{Y}_{t}+\mu \gamma_{l} \hat{B}_{t-1}+\phi_{k l} u_{t}^{k}+\phi_{l c} u_{t}^{c}+u_{t}^{l} \\
\hat{\tau}_{t}^{c} & =\phi_{k c} u_{t}^{k}+\phi_{l c} u_{t}^{l}+u_{t}^{c} \\
\hat{Z}_{t} & =-\varphi_{Z} \hat{Y}_{t}-\mu \gamma_{Z} \hat{B}_{t-1}+u_{t}^{z} .
\end{aligned}
$$

where $\mu \in(0.05,3.0)$ is the scaling parameter. $\mu=0.05$ is the slowest speed of adjustment consistent with equilibrium. Setting $\mu=1$ (vertical lines in the figure) reproduces the multipliers for the posterior mean. When $\mu<1$, fiscal adjustments are slower and debt accumulates more rapidly; $\mu>1$ accelerates fiscal adjustments, ensuring less debt accumulation.

Figure 9 compares present-value multipliers for output for each of the fiscal shocksgovernment spending, capital taxes, labor taxes, and transfers - under alternative sets of the fiscal adjustment parameters. Present-value multipliers are expressed as a function of the scaling parameter $\mu$ at various horizons: at impact (solid lines, horizon $=1$ ) and at quarters 5 (dotted-dashed lines), 10 (dashed lines), and 25 (dotted lines).

Government spending multipliers are smaller at every horizon when fiscal adjustment accelerates, a pattern that also applies to labor tax multipliers (two left-hand panels). When

\footnotetext{
${ }^{13}$ Because the subsample dates considered in Smets and Wouters (2007) differ slightly from those considered here and Smets and Wouters use a different specification of capacity utilization, comparisons between our results and theirs should be made with caution.
} 
capital tax shocks are financed more rapidly the multiplier decline, but only at shorter horizons. Medium-run present-value multipliers (25-quarter horizon) display a non-monotonic pattern at very slow speeds of adjustment, before actually rising with the speed of adjustment once $\mu>0.25$.

5.2. Alternative Financing Schemes. The patterns that emerge from figure 9, in which all instruments adjust, can change in important ways when only a single instrument takes on the burden of stabilizing debt. The second counterfactual exercise varies both the source of fiscal financing - restricting it to adjustment by only a single instrument - and the speed of adjustment. We also eliminate the correlation among tax shocks estimated in the best fitting model.

Figure 10 reports present-value multipliers for output from changes in government spending, labor tax rates, and capital tax rates. The figure extends the forecast horizon to 50 years in order to highlight the differences between short-to-medium-run multipliers and long-run multipliers. The counterfactual allows capital taxes, labor taxes, or government spending to adjust one at a time. Slower adjustment (solid lines) scales the parameter on debt in the rule for the adjusting instrument by setting $\mu=0.5$, while faster adjustment (dashed lines) scales the parameter by setting $\mu=2.0$ in the policy rules (21)-(23).

When future capital taxes alone stabilize debt, slower adjustment raises government spending multipliers at shorter horizons, but at the cost of smaller multipliers over longer horizons (top left panel). Regardless of the speed of adjustment, when capital taxes back debt that is issued to finance government spending, the present-value multiplier rapidly turns negative and can easily exceed -1.0 . When labor taxes adjust, on the other hand, there appears to be no tradeoff: slower adjustment raises the government spending multiplier over the entire 50-year horizon.

If government spending adjusts to debt following an increase in either capital or labor tax rates, interesting non-monotonicities set in (second and third panels on left). In the short run, slower adjustment enhances multipliers, but over longer horizons, slower adjustment reduces the present-value multipliers for taxes. In the case of labor tax shocks, multipliers change sign, with the sign change occurring much sooner when debt stabilization is rapid.

Labor tax multipliers change sign very quickly when capital taxes adjust to debt, with higher labor taxes lowering output only briefly (second panel on right). In the medium and long runs, higher labor taxes raise output substantially because capital taxes are persistently lower to satisfy the government's present-value relation. Finally, when labor taxes stabilize debt following a shock to capital taxes, the present-value multiplier is uniformly larger when labor taxes adjust more slowly (bottom right panel). 
5.3. Enhanced "Automatic Stabilizers". The final counterfactual exercise examines the consequences of increasing or decreasing the "automatic stabilizer" aspect of the fiscal rulesthe $\varphi$ coefficients on contemporaneous output in policy rules (11), (12), (13), and (15). Specifically, we ask how the government spending present-value multiplier for output changes when capital taxes alone adjust to stabilize debt, as in the top left panel of figure 10, and the degree of "automatic" responsiveness of fiscal variables to output fluctuations changes.

Figure 11 reports the present-value multipliers for four different settings of the $\varphi$ coefficients: no automatic response (dashed line); estimated responses (solid line); twice the estimated responses (dotted line); three times the estimated responses (dotted-dashed line). Stronger "automatic stabilizers," which may help to reduce the short-run fluctuations induced by various shocks, impose a long-run cost. In this example, higher government spending initially raises output, which under the estimated policies, raises capital and labor taxes and lowers transfers.

But in this scenario, higher expected taxes on capital quickly reverse the initial stimulus to output. Naturally, "automatic stabilizers" are symmetric: when output falls, the declines in tax revenues and increases in government expenditures are amplified, reducing future surpluses still more. Capital taxes, therefore, must rise more sharply to stabilize debt. Stronger countercyclical responses exacerbate the decline in future surpluses and require more dramatic tax hikes, which drive output still lower. This counterfactual shows that short-run countercyclical fiscal behavior can make the long-run multiplier for government spending dramatically different.

\section{Concluding Remarks}

Even a casual observer of the fiscal policy process acknowledges that it is immensely complex. The estimates from the model with the best fit to data make this point precise: shocks that raise government debt outstanding trigger dynamic reactions in government spending, capital and labor taxes, and transfer payments that can take many decades to play out fully. The practice of examining the macroeconomic consequences of fiscal changes without also studying the resulting debt dynamics and subsequent fiscal adjustments is sharply at odds with time series data.

Three central messages emerge from the estimates:

(1) Assumptions about which fiscal instruments may adjust to stabilize debt are very important for the ultimate impacts of changes in fiscal policy.

(2) The speed at which government debt is stabilized following a fiscal disturbance plays a critical role in determining the effects of the shock on the macro economy. 
(3) Because debt-financed fiscal changes trigger very long-lived dynamics, even in completely conventional models, short-run impacts can differ sharply from long-run effects, even being of different signs.

Although the dynamic interactions among policy variables in the estimated models are complex, understanding these complexities is just the first step in understanding how fiscal policy affects the economy. Introducing non-neutral transfer payments [Blanchard (1985), Weil (1987), Forni, Monteforte, and Sessa (2009)], a distinction between productive and unproductive government spending [Aschauer (1989), Baxter and King (1993)], monetary policy behavior [Leeper and Sims (1994), Kim (2000)], and the possibility of fiscal foresight [Leeper, Walker, and Yang (2009)], is a short list of further complications worthy of modeling attention. 


\section{Appendix A. Derivations of Model Equations}

This appendix derives of the log-linearized model used for estimation.

A.1. Equilibrium Conditions. Define $q_{t}=\frac{\mu_{t}}{\lambda_{t}}$.

$$
\begin{aligned}
& \frac{u_{t}^{b}\left(C_{t}-h C_{t-1}\right)^{-\gamma}}{1+\tau_{t}^{c}}=E_{t} \frac{\beta R_{t} u_{t+1}^{b}\left(C_{t+1}-h C_{t}\right)^{-\gamma}}{1+\tau_{t+1}^{c}} \\
& u_{t}^{l} L_{t}^{1+\kappa}\left(1+\tau_{t}^{c}\right)=\left(C_{t}-h C_{t-1}\right)^{-\gamma}\left(1-\tau_{t}^{l}\right)(1-\alpha) Y_{t} \\
& q_{t}=\beta E_{t} \frac{u_{t+1}^{b}\left(C_{t+1}-h C_{t}\right)^{-\gamma}\left(1-\tau_{t}^{c}\right)}{u_{t}^{b}\left(C_{t}-h C_{t-1}\right)^{-\gamma}\left(1+\tau_{t+1}^{c}\right)}\left\{\left(1-\tau_{t+1}^{K}\right) \frac{\alpha Y_{t+1}}{K_{t}}+q_{t+1}\left[1-\delta\left(v_{t+1}\right)\right]\right\} \\
& \frac{\alpha Y_{t}\left(1-\tau_{t}^{k}\right)}{v_{t} K_{t-1}}=q_{t}\left[\delta_{1}+\delta_{2}\left(v_{t}-1\right)\right] \\
& 1=q_{t}\left\{\left[1-s_{t}(\cdot)\right]-s_{t}^{\prime}(\cdot) \frac{u_{t}^{i} I_{t}}{I_{t-1}}\right\}+\beta E_{t}\left\{\frac{\lambda_{t+1}}{\lambda_{t}} q_{t+1} s_{t+1}^{\prime}(\cdot)\left(\frac{u_{t+1}^{i} I_{t+1}}{I_{t}}\right)^{2}\right\} \\
& Y_{t}=C_{t}+G_{t}+I_{t} \\
& K_{t}=\left[1-\delta\left(v_{t}\right)\right] K_{t-1}+\left[1-s\left(\frac{u_{t}^{i} I_{t}}{I_{t-1}}\right)\right] I_{t} \\
& B_{t}+T_{t}^{k}+T_{t}^{l}+T_{t}^{c}=R_{t-1} B_{t-1}+G_{t}+Z_{t} \\
& T_{t}^{k}=\tau_{t}^{k} \alpha Y_{t} \\
& T_{t}^{l}=\tau_{t}^{l}(1-\alpha) Y_{t} \\
& T_{t}^{c}=\tau_{t}^{c} C_{t} \\
& Y_{t}=u_{t}^{a}\left(v_{t} K_{t-1}\right)^{\alpha}\left(L_{t}\right)^{1-\alpha}
\end{aligned}
$$

Equations (A.1)-(A.12) along with the fiscal policy rules, equations (11)-(15) in the text and the shock processes defined in the text, equations (1), (2), (5), and (8), define a competitive equilibrium. 


\section{A.2. Steady State.}

$$
\begin{gathered}
q=1, \quad v=1 \\
R=\frac{1}{\beta} \\
R^{k}=\frac{\frac{1}{\beta}-\left(1-\delta_{0}\right)}{1-\tau^{k}} \\
\delta_{1}=R^{k}\left(1-\tau^{k}\right) \\
I=\delta_{0} K
\end{gathered}
$$

$Y, K, C$, and $L$ can be solved from the following set of equations:

$$
\begin{aligned}
Y\left(1-s_{g}\right) & =C+\delta_{0} K \\
Y & =K^{\alpha} L^{1-\alpha} \\
R^{k} & =\frac{\alpha Y}{K} \\
\left(1+\tau^{c}\right) L^{1+\kappa} & =(C-h C)^{-\gamma}\left(1-\tau^{l}\right)(1-\alpha) Y
\end{aligned}
$$

where $s_{g}=G / Y \in(0,1)$. Finally, $Z$ can be solved for from the government budget constraint:

$$
Z=\tau^{k} \alpha Y+\tau^{l}(1-\alpha) Y+\tau^{c} C-Y\left(s_{g}+\frac{1-\beta}{\beta} s_{b}\right)
$$

where $s_{b}=B / Y \in(0,1)$.

\section{A.3. Log-Linearized System.}

$$
\begin{gathered}
\hat{u}_{t}^{b}-\frac{\gamma(1+h)}{1-h} \hat{C}_{t}+\frac{\gamma h}{1-h} \hat{C}_{t-1}-\frac{\tau^{c}}{1+\tau^{c}} \hat{\tau}_{t}^{c}=\hat{R}_{t}-\frac{\tau^{c}}{1+\tau^{c}} E_{t} \hat{\tau}_{t+1}^{c}+E_{t} u_{t+1}^{b}-\frac{\gamma}{1-h} E_{t} \hat{C}_{t+1} \\
\hat{u}_{t}^{l}+(1+\kappa) \hat{L}_{t}+\frac{\tau^{c}}{1+\tau^{c}} \hat{\tau}_{t}^{c}=\hat{Y}_{t}-\frac{\tau^{l}}{1-\tau^{l}} \hat{\tau}_{t}^{l}-\frac{\gamma}{1-h} \hat{C}_{t}+\frac{\gamma h}{1-h} \hat{C}_{t-1} \\
\hat{q}_{t}=E_{t} \hat{u}_{t+1}^{b}-\frac{\gamma}{1-h} E_{t} \hat{C}_{t+1}+\frac{\gamma(1+h)}{1-h} \hat{C}_{t}-\frac{\tau^{c}}{1+\tau^{c}} E_{t} \hat{\tau}_{t+1}^{c}-\hat{u}_{t}^{b}-\frac{\gamma h}{1-h} \hat{C}_{t-1}+\frac{\tau^{c}}{1+\tau^{c}} \hat{\tau}_{t}^{c} \\
+\beta\left(1-\tau^{k}\right) \alpha \frac{Y}{K} E_{t} \hat{Y}_{t+1}-\beta\left(1-\tau^{k}\right) \alpha \frac{Y}{K} \hat{K}_{t}-\beta \tau^{k} \alpha \frac{Y}{K} E_{t} \hat{\tau}_{t+1}^{k} \\
-\beta \delta_{1} E_{t} \hat{v}_{t+1}+\beta\left(1-\delta_{0}\right) E_{t} \hat{q}_{t+1} \\
\hat{Y}_{t}-\frac{\tau^{k}}{1-\tau^{k}} \hat{\tau}_{t}^{k}-\hat{K}_{t-1}=\hat{q}_{t}+\left(1+\frac{\delta_{2}}{\delta_{1}}\right) \hat{v}_{t} \\
\frac{1}{s^{\prime \prime}(1)} \hat{q}_{t}-(1+\beta) \hat{I}_{t}+\hat{I}_{t-1}+\beta E_{t} \hat{I}_{t+1}-\hat{u}_{t}^{i}+\beta E_{t} \hat{u}_{t+1}^{i}=0 \\
Y \hat{Y}_{t}=C \hat{C}_{t}+G \hat{G}_{t}+I \hat{I}_{t} \\
\hat{K}_{t}=\left(1-\delta_{0}\right) \hat{K}_{t-1}+\delta_{1} \hat{v}_{t}+\delta_{0} \hat{I}_{t}
\end{gathered}
$$




$$
\begin{gathered}
B \hat{B}_{t}+\tau^{k} \alpha Y\left(\hat{\tau}_{t}^{k}+\hat{Y}_{t}\right)+\tau^{l}(1-\alpha) Y\left(\hat{\tau}_{t}^{l}+\hat{Y}_{t}\right)+\tau^{c} C\left(\hat{\tau}_{t}^{c}+\hat{C}_{t}\right)=\frac{B}{\beta} \hat{R}_{t-1}+\frac{B}{\beta} \hat{B}_{t-1}+G \hat{G}_{t}+Z \hat{Z}_{t} \\
\hat{Y}_{t}=\hat{u}_{t}^{a}+\alpha \hat{v}_{t}+\alpha \hat{K}_{t-1}+(1-\alpha) \hat{L}_{t}
\end{gathered}
$$

These equations, along with the exogenous processes given by equations (1), (2), (5), (8), and (11)-(15) in the text, comprise the set of equations used to solve the model using Sims's (2001) algorithm.

\section{Appendix B. Data Construction}

Unless otherwise noted, all data are from the Bureau of Economic Analysis' NIPA. All data in levels are nominal values. Nominal data are converted to real values by dividing by the GDP deflator.

P: The GDP deflator for personal consumption expenditures (line 2 in Table 1.1.4)

M: The St. Louis adjusted monetary base. Quarterly rates are computed as averages of monthly rates.

Consumption Tax Revenues. The consumption tax revenues, $T^{c}$, include excise taxes and customs duties (lines 5 and 6 in NIPA Table 3.2).

Consumption Tax Rates. The average consumption tax rate is defined as

$$
\tau^{c}=\frac{T^{c}}{C-T^{c}-T_{s}^{c}}
$$

where $C$ is personal consumption expenditure on nondurable goods (table 1.1.5 line 4) and on services (table 1.1.5 line 5 ) and $T_{s}^{c}$ is state and local sales taxes (table 3.3 line 12). ${ }^{14}$

Capital and Labor Tax Rates. Following Jones (2002), first the average personal income tax rate is computed:

$$
\tau^{p}=\frac{\mathrm{IT}}{\mathrm{W}+\mathrm{PRI} / 2+\mathrm{CI}}
$$

where IT is personal current tax revenues (table 3.2 line 3 ), $\mathrm{W}$ is wage and salary accruals (table 1.12 line 3), PRI is proprietors' income (table 1.12 line 3), and CI is capital income. Capital income is defined as rental income (table 1.12 line 12), corporate profits (table 1.12 line 13), interest income (table 1.12 line 18), and PRI/2.

The average labor income tax rate is computed as:

$$
\tau^{l}=\frac{\tau^{p}(W+P R I / 2)+C S I}{E C+P R I / 2}
$$

\footnotetext{
${ }^{14}$ Quarterly data for sales taxes is not available until 1958. From 1947 to 1957, the annual values are used for all four quarters.
} 
where CSI is contributions for government social insurance (table 3.2 line 11) and EC is compensation of employees (table 1.12 line 2). The average capital income tax rate is calculated as:

$$
\tau^{k}=\frac{\tau^{p} C I+C T}{C I+P T}
$$

where CT is taxes on corporate income (table 3.2 line 7 ) and PT is property taxes (table 3.3 line 8). ${ }^{15}$

Capital and Labor Tax Revenues. The capital and labor tax revenues are constructed by multiplying the average tax rate and tax base.

Government Expenditure. Government expenditure, G, is defined as government consumption expenditure (table 3.2 line 20), government gross investment (table 3.2 line 41), and government net purchases of non-produced assets (table 3.2 line 43), minus government consumption of fixed capital (table 3.2 line 44).

Transfers. Transfers, TR, are defined as net current transfers, net capital transfers, and subsidies (table 3.2 line 31), minus the tax residual. Net current transfers are defined as current transfer payments (table 3.2 line 21) minus current transfer receipts (table 3.2 line 15). Net capital transfers are defined as capital transfer payments (table 3.2 line 42) minus capital transfer receipts (table 3.2 line 38). The tax residual is defined as current tax receipts (table 3.2 line 2), contributions for government social insurance (table 3.2 line 11), income receipts on assets (table 3.2 line 12), and the current surplus of government enterprises (table 3.2 line 18), minus total tax revenue, $\mathrm{T}$ (consumption, labor, and capital tax revenues).

Government Debt. Government debt, $B$, is defined as:

$$
B_{t}=N B-\text { Seigniorage }+B_{t-1}
$$

where Seigniorage is defined as $M_{t}-M_{t-1}$ and NB is net borrowing. Net borrowing is computed using the NIPA deficits concept, specifically as $G+I N T+T R-T$, where $I N T$ is interest payments (table 3.2 line 28). ${ }^{16}$

Hours Worked. Hours worked is constructed from the following variables:

H: Nonfarm Business, All Persons, Average Weekly Hours Duration : index, $1992=$ 100, Seasonally Adjusted. (from U.S. Department of Labor, PRS85006023).

\footnotetext{
${ }^{15}$ Although $\tau_{k}$ and $\tau_{l}$ are computed using quarterly data, quarterly data for property taxes is not available until 1958. For 1947 to 1957, the annual values are used for all four quarters.

${ }^{16} 1947: 1$ debt is not calculated with this definition, but is set at the value of the Cox and Hirschhorn (1983) market value of debt for 1947:1. The Cox-Hirschhorn debt series is not used in general since the series is not consistent with NIPA's net borrowing definition. However, the correlation between the debt series in this paper and the Cox-Hirschhorn debt series, which is maintained and updated at the Federal Reserve Bank of Dallas, is approximately 0.998
} 
Emp: Civilian Employment: Sixteen Years \& Over, measured in thousands, Seasonally Adjusted. (from U.S. Department of Labor, Bureau of Labor Statistics, CE16OV). Turned into an index where 1992:3 $=100$.

Hours worked are then defined as

$$
N=\frac{\mathrm{H} * \mathrm{Emp}}{100}
$$

Definitions of Observable Variables. The observable variable $X$ is defined by making the following transformation to variable $x$ :

$$
X=\ln \left(\frac{x}{\text { Popindex }}\right) * 100
$$

where

Popindex: index of Pop, constructed so that 1992:3 = 1 .

Pop: Civilian noninstitutional population, ages 16 years and over, Seasonally Adjusted. Number in thousands (from U.S. Bureau of Labor Statistics), LNS10000000.

and $x=$ consumption, investment, hours worked, government spending, labor tax revenues, capital tax revenues, consumption tax revenues, government debt, and transfers. 
DYNAMICS OF FISCAL FINANCING IN THE UNITED STATES

\begin{tabular}{ll} 
Parameter & Value \\
\hline$\beta$ & 0.99 \\
$\delta_{0}$ & 0.025 \\
$\alpha$ & 0.30 \\
$G / Y$ & 0.0922 \\
$B / Y$ & 0.3396 \\
$\tau^{k}$ & 0.184 \\
$\tau^{l}$ & 0.223 \\
$\tau^{c}$ & 0.028
\end{tabular}

TABle 1. Calibrated Parameters for Estimated Model 


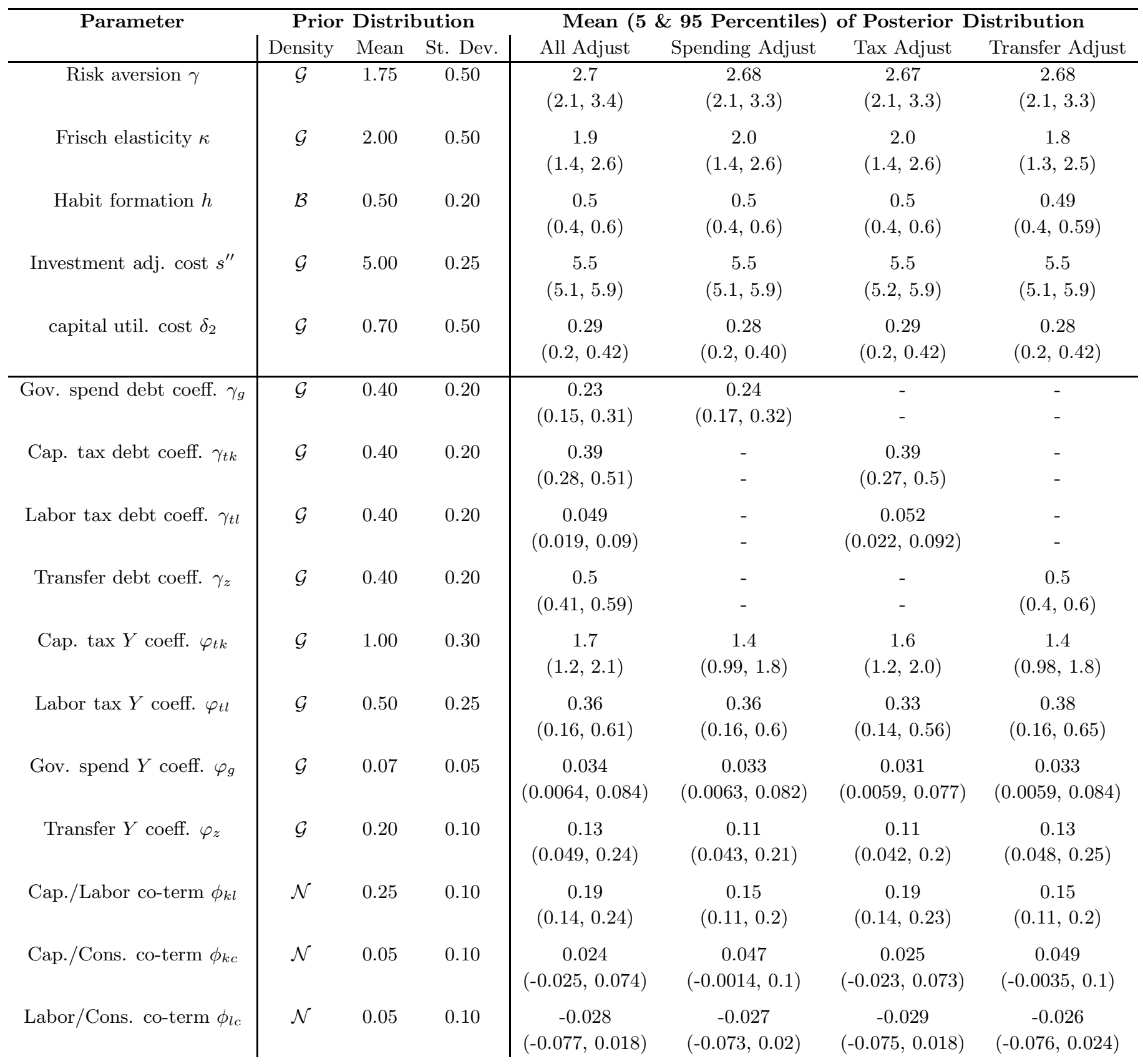

TABLE 2. Selected prior and posterior distributions for the various models estimated. 


\begin{tabular}{|c|c|c|c|c|c|c|c|}
\hline \multirow[t]{2}{*}{ Parameter } & \multicolumn{3}{|c|}{ Prior Distribution } & \multicolumn{4}{|c|}{ Mean (5 \& 95 Percentiles) of Posterior Distribution } \\
\hline & Density & Mean & St. Dev. & All Adjust & Spending Adjust & Tax Adjust & Transfer Adjust \\
\hline Tech. AR coeff. $\rho_{a}$ & $\mathcal{B}$ & 0.70 & 0.20 & $\begin{array}{c}0.96 \\
(0.94,0.98)\end{array}$ & $\begin{array}{c}0.96 \\
(0.94,0.98)\end{array}$ & $\begin{array}{c}0.96 \\
(0.94,0.98)\end{array}$ & $\begin{array}{c}0.96 \\
(0.94,0.98)\end{array}$ \\
\hline Pref. AR coeff. $\rho_{b}$ & $\mathcal{B}$ & 0.70 & 0.20 & $\begin{array}{c}0.66 \\
(0.62,0.69)\end{array}$ & $\begin{array}{c}0.66 \\
(0.62,0.69)\end{array}$ & $\begin{array}{c}0.66 \\
(0.62,0.69)\end{array}$ & $\begin{array}{c}0.66 \\
(0.62,0.70)\end{array}$ \\
\hline Labor AR coeff. $\rho_{l}$ & $\mathcal{B}$ & 0.70 & 0.20 & $\begin{array}{c}0.99 \\
(0.97,0.99)\end{array}$ & $\begin{array}{c}0.99 \\
(0.97,0.99)\end{array}$ & $\begin{array}{c}0.99 \\
(0.97,0.99)\end{array}$ & $\begin{array}{c}0.98 \\
(0.96,0.99)\end{array}$ \\
\hline Inv. AR coeff. $\rho_{i}$ & $\mathcal{B}$ & 0.70 & 0.20 & $\begin{array}{c}0.55 \\
(0.47,0.64)\end{array}$ & $\begin{array}{c}0.53 \\
(0.45,0.62)\end{array}$ & $\begin{array}{c}0.52 \\
(0.44,0.61)\end{array}$ & $\begin{array}{c}0.58 \\
(0.49,0.66)\end{array}$ \\
\hline Gov. spend AR coeff. $\rho_{g}$ & $\mathcal{B}$ & 0.70 & 0.20 & $\begin{array}{c}0.97 \\
(0.95,0.99)\end{array}$ & $\begin{array}{c}0.97 \\
(0.95,0.99)\end{array}$ & $\begin{array}{c}0.97 \\
(0.94,0.99)\end{array}$ & $\begin{array}{c}0.96 \\
(0.93,0.98)\end{array}$ \\
\hline Cap. tax AR coeff. $\rho_{t k}$ & $\mathcal{B}$ & 0.70 & 0.20 & $\begin{array}{c}0.93 \\
(0.9,0.97)\end{array}$ & $\begin{array}{c}0.91 \\
(0.88,0.95)\end{array}$ & $\begin{array}{c}0.94 \\
(0.9,0.97)\end{array}$ & $\begin{array}{c}0.91 \\
(0.87,0.93)\end{array}$ \\
\hline Labor tax AR coeff. $\rho_{t l}$ & $\mathcal{B}$ & 0.70 & 0.20 & $\begin{array}{c}0.97 \\
(0.95,0.99)\end{array}$ & $\begin{array}{c}0.97 \\
(0.95,0.99)\end{array}$ & $\begin{array}{c}0.97 \\
(0.95,0.99)\end{array}$ & $\begin{array}{c}0.97 \\
(0.94,0.99)\end{array}$ \\
\hline Cons. tax AR coeff. $\rho_{t c}$ & $\mathcal{B}$ & 0.70 & 0.20 & $\begin{array}{c}0.93 \\
(0.89,0.97)\end{array}$ & $\begin{array}{c}0.93 \\
(0.89,0.97)\end{array}$ & $\begin{array}{c}0.93 \\
(0.9,0.97)\end{array}$ & $\begin{array}{c}0.93 \\
(0.9,0.97)\end{array}$ \\
\hline Transfer AR coeff. $\rho_{z}$ & $\mathcal{B}$ & 0.70 & 0.20 & $\begin{array}{c}0.94 \\
(0.91,0.98)\end{array}$ & $\begin{array}{c}0.97 \\
(0.94,0.99)\end{array}$ & $\begin{array}{c}0.97 \\
(0.94,0.99)\end{array}$ & $\begin{array}{c}0.95 \\
(0.91,0.98)\end{array}$ \\
\hline Tech std $\sigma_{a}$ & $\mathcal{I} \mathcal{G}^{1}$ & 1 & 4 & $\begin{array}{c}0.62 \\
(0.58,0.68)\end{array}$ & $\begin{array}{c}0.63 \\
(0.58,0.68)\end{array}$ & $\begin{array}{c}0.62 \\
(0.58,0.68)\end{array}$ & $\begin{array}{c}0.62 \\
(0.57,0.68)\end{array}$ \\
\hline Pref. std $\sigma_{b}$ & $\mathcal{I} \mathcal{G}^{1}$ & 1 & 4 & $\begin{array}{c}7 \\
(6.4,7.7)\end{array}$ & $\begin{array}{c}7 \\
(6.4,7.7)\end{array}$ & $\begin{array}{c}6.9 \\
(6.3,7.6)\end{array}$ & $\begin{array}{c}7 \\
(6.4,7.8)\end{array}$ \\
\hline Labor std $\sigma_{l}$ & $\mathcal{I G}^{1}$ & 1 & 4 & $\begin{array}{c}2.8 \\
(2.3,3.5)\end{array}$ & $\begin{array}{c}2.9 \\
(2.3,3.5)\end{array}$ & $\begin{array}{c}2.9 \\
(2.3,3.5)\end{array}$ & $\begin{array}{c}2.8 \\
(2.2,3.4)\end{array}$ \\
\hline Inv. std $\sigma_{i}$ & $\mathcal{I G}^{1}$ & 1 & 4 & $\begin{array}{c}6.4 \\
(5.7,7.2)\end{array}$ & $\begin{array}{c}6.2 \\
(5.6,7)\end{array}$ & $\begin{array}{c}6.2 \\
(5.5,6.9)\end{array}$ & $\begin{array}{c}6.6 \\
(5.8,7.5)\end{array}$ \\
\hline Gov. spend std $\sigma_{g}$ & $\mathcal{I} \mathcal{G}^{1}$ & 1 & 4 & $\begin{array}{c}3.1 \\
(2.8,3.3)\end{array}$ & $\begin{array}{c}3.1 \\
(2.8,3.3)\end{array}$ & $\begin{array}{c}3.1 \\
(2.9,3.4)\end{array}$ & $\begin{array}{c}3.1 \\
(2.9,3.4)\end{array}$ \\
\hline Cap. tax std $\sigma_{t k}$ & $\mathcal{I} \mathcal{G}^{1}$ & 1 & 4 & $\begin{array}{c}4.4 \\
(4.1,4.7)\end{array}$ & $\begin{array}{c}4.6 \\
(4.3,4.9)\end{array}$ & $\begin{array}{c}4.4 \\
(4.1,4.7)\end{array}$ & $\begin{array}{c}4.6 \\
(4.2,5)\end{array}$ \\
\hline Labor tax std $\sigma_{t l}$ & $\mathcal{I} \mathcal{G}^{1}$ & 1 & 4 & $\begin{array}{c}3 \\
(2.8,3.2)\end{array}$ & $\begin{array}{c}3 \\
(2.8,3.2)\end{array}$ & $\begin{array}{c}3 \\
(2.8,3.2)\end{array}$ & $\begin{array}{c}3 \\
(2.8,3.3)\end{array}$ \\
\hline Cons. tax std $\sigma_{t c}$ & $\mathcal{I} \mathcal{G}^{1}$ & 1 & 4 & $\begin{array}{c}4 \\
(3.8,4.4)\end{array}$ & $\begin{array}{c}4 \\
(3.8,4.3)\end{array}$ & $\begin{array}{c}4 \\
(3.8,4.4)\end{array}$ & $\begin{array}{c}4 \\
(3.7,4.4)\end{array}$ \\
\hline Transfer std $\sigma_{z}$ & $\mathcal{I} \mathcal{G}^{1}$ & 1 & 4 & $\begin{array}{c}3.4 \\
(3.1,3.7)\end{array}$ & $\begin{array}{c}3.9 \\
(3.6,4.2)\end{array}$ & $\begin{array}{c}3.9 \\
(3.6,4.2)\end{array}$ & $\begin{array}{c}3.4 \\
(3.1,3.7)\end{array}$ \\
\hline
\end{tabular}

1: The parameters for the Inverse Gamma distribution correspond to $s$ and $\nu$ where $f(x \mid s, \nu)=\nu^{s} \Gamma^{-1}(s) x^{-s-1} \exp ^{\frac{-\nu}{x}}$.

TABLE 3. Selected prior and posterior distributions for the various models estimated. 


\begin{tabular}{|c|c|c|}
\hline Model Specification & $\begin{array}{l}\text { Log Marginal } \\
\text { Data Density }\end{array}$ & $\begin{array}{l}\text { Bayes Factor Relative to } \\
\text { Model Where All Adjust }\end{array}$ \\
\hline All fiscal instruments adjust & -68 & 1.0 \\
\hline Only government spending adjusts & -97 & $\exp [29]$ \\
\hline Only taxes adjust & -102 & $\exp [34]$ \\
\hline Only transfers adjust & -75 & $\exp [7]$ \\
\hline \multicolumn{3}{|l|}{ Addendum } \\
\hline $\begin{array}{l}\text { Only transfers adjust, } \\
\text { o output response or tax comovemen }\end{array}$ & -86 & $\exp [18]$ \\
\hline
\end{tabular}

TABle 4. Model Fit Comparisons 
Government Spending Present-Value Multipliers

\begin{tabular}{lccccc} 
Variable & 1 quarter & 5 quarters & 10 quarters & 25 quarters & $\infty$ \\
\hline$\frac{\mathrm{PV}(\Delta Y)}{\mathrm{PV}(\Delta G)}$ & 0.64 & 0.43 & 0.33 & 0.20 & 0.03 \\
$\mathrm{PV}(\Delta C)$ & -0.26 & -0.34 & -0.35 & -0.40 & -0.60 \\
$\mathrm{PV}(\Delta G)$ & & & & & \\
$\mathrm{PV}(\Delta I)$ & -0.10 & -0.23 & -0.32 & -0.40 & -0.36
\end{tabular}

\section{Capital Tax Present-Value Multipliers}

\begin{tabular}{cccccc} 
Variable & 1 quarter & 5 quarters & 10 quarters & 25 quarters & $\infty$ \\
\hline$\frac{\mathrm{PV}(\Delta Y)}{\mathrm{PV}\left(\Delta T^{k}\right)}$ & -0.18 & -0.26 & -0.33 & -0.50 & -0.72 \\
$\frac{\mathrm{PV}(\Delta C)}{\mathrm{PV}\left(\Delta T^{k}\right)}$ & -0.076 & -0.11 & -0.11 & -0.19 & -0.47 \\
$\frac{\mathrm{PV}(\Delta I)}{\mathrm{PV}\left(\Delta T^{k}\right)}$ & -0.11 & -0.30 & -0.47 & -0.64 & -0.60
\end{tabular}

\section{Labor Tax Present-Value Multipliers}

\begin{tabular}{cccccc} 
Variable & 1 quarter & 5 quarters & 10 quarters & 25 quarters & $\infty$ \\
\hline$\frac{\mathrm{PV}(\Delta Y)}{\mathrm{PV}\left(\Delta T^{l}\right)}$ & -0.19 & -0.19 & -0.19 & -0.19 & -0.21 \\
$\frac{\mathrm{PV}(\Delta C)}{\mathrm{PV}\left(\Delta T^{l}\right)}$ & -0.17 & -0.26 & -0.29 & -0.33 & -0.37 \\
$\frac{\mathrm{PV}(\Delta I)}{\mathrm{PV}\left(\Delta T^{l}\right)}$ & -0.02 & -0.03 & -0.04 & -0.05 & -0.04
\end{tabular}

\section{Transfers Present-Value Multipliers}

\begin{tabular}{cccccc} 
Variable & 1 quarter & 5 quarters & 10 quarters & 25 quarters & $\infty$ \\
\hline$\frac{\mathrm{PV}(\Delta Y)}{\mathrm{PV}(\Delta Z)}$ & -0.02 & -0.16 & -0.28 & -0.46 & -0.59 \\
$\frac{\mathrm{PV}(\Delta C)}{\mathrm{PV}(\Delta Z)}$ & 0.01 & 0.07 & 0.13 & 0.18 & 0.12 \\
$\frac{\mathrm{PV}(\Delta I)}{\mathrm{PV}(\Delta Z)}$ & -0.03 & -0.09 & -0.15 & -0.23 & -0.23
\end{tabular}

TABle 5. Present-value fiscal multipliers when all fiscal instruments respond to debt. Mean estimates of posterior draws from best fiting model in which all fiscal instruments - government spending, capital taxes, labor taxes, and transfers - adjust to stabilize debt. 
Government Spending Present-Value Multipliers

\begin{tabular}{lccccc} 
Variable & 1 quarter & 5 quarters & 10 quarters & 25 quarters & $\infty$ \\
\hline$\frac{\mathrm{PV}(\Delta Y)}{\mathrm{PV}(\Delta G)}$ & 0.59 & 0.32 & 0.14 & -0.21 & -0.99 \\
$\mathrm{PV}(\Delta C)$ & -0.24 & -0.28 & -0.27 & -0.33 & -0.89 \\
$\mathrm{PV}(\Delta G)$ & & & & & \\
$\mathrm{PV}(\Delta I)$ & -0.17 & -0.40 & -0.59 & -0.88 & -1.10
\end{tabular}

\section{Capital Tax Present-Value Multipliers}

\begin{tabular}{cccccc} 
Variable & 1 quarter & 5 quarters & 10 quarters & 25 quarters & $\infty$ \\
\hline$\frac{\mathrm{PV}(\Delta Y)}{\mathrm{PV}\left(\Delta T^{k}\right)}$ & -0.14 & -0.20 & -0.18 & 0.42 & -3.70 \\
$\frac{\mathrm{PV}(\Delta C)}{\mathrm{PV}\left(\Delta T^{k}\right)}$ & -0.10 & -0.14 & -0.18 & -0.52 & -0.83 \\
$\frac{\mathrm{PV}(\Delta I)}{\mathrm{PV}\left(\Delta T^{k}\right)}$ & -0.04 & -0.06 & 0.01 & 0.94 & -2.90
\end{tabular}

\section{Labor Tax Present-Value Multipliers}

\begin{tabular}{cccccc} 
Variable & 1 quarter & 5 quarters & 10 quarters & 25 quarters & $\infty$ \\
\hline$\frac{\mathrm{PV}(\Delta Y)}{\mathrm{PV}\left(\Delta T^{l}\right)}$ & -0.14 & -0.12 & -0.04 & 0.22 & 0.92 \\
$\frac{\mathrm{PV}(\Delta C)}{\mathrm{PV}\left(\Delta T^{l}\right)}$ & -0.19 & -0.30 & -0.34 & -0.36 & 0.06 \\
$\frac{\mathrm{PV}(\Delta I)}{\mathrm{PV}\left(\Delta T^{l}\right)}$ & 0.05 & 0.17 & 0.31 & 0.58 & 0.87
\end{tabular}

\section{Transfers Present-Value Multipliers}

\begin{tabular}{cccccc} 
Variable & 1 quarter & 5 quarters & 10 quarters & 25 quarters & $\infty$ \\
\hline$\frac{\mathrm{PV}(\Delta Y)}{\mathrm{PV}(\Delta Z)}$ & -0.07 & -0.19 & -0.33 & -0.64 & -1.40 \\
$\frac{\mathrm{PV}(\Delta C)}{\mathrm{PV}(\Delta Z)}$ & 0.04 & 0.10 & 0.14 & 0.11 & -0.38 \\
$\frac{\mathrm{PV}(\Delta I)}{\mathrm{PV}(\Delta Z)}$ & -0.11 & -0.30 & -0.46 & -0.75 & -0.98
\end{tabular}

TABle 6. Present-value fiscal multipliers when only capital and labor taxes respond to debt. Mean estimates of posterior draws from model in which only taxl instruments - capital and labor tax rates - adjust to stabilize debt. 


\begin{tabular}{c|ccccccccc}
\hline Variable & \multicolumn{7}{|c}{ Shock } \\
& $\epsilon_{t}^{a}$ & $\epsilon_{t}^{c}$ & $\epsilon_{t}^{l}$ & $\epsilon_{t}^{i}$ & $\epsilon_{t}^{g}$ & $\epsilon_{t}^{\tau^{k}}$ & $\epsilon_{t}^{\tau^{l}}$ & $\epsilon_{t}^{\tau^{c}}$ & $\epsilon_{t}^{z}$ \\
\hline$G$ & -9.68 & 14.39 & 17.04 & 2.26 & -24.55 & -2.30 & -4.95 & -2.70 & 3.08 \\
$T^{k}$ & 10.14 & 2.02 & -19.61 & -3.85 & 7.54 & 5.90 & -4.41 & -1.77 & 3.12 \\
$T^{l}$ & 19.18 & -11.39 & -35.52 & -5.96 & 1.85 & 2.01 & 22.98 & -2.74 & 0.25 \\
$T^{c}$ & 2.10 & -0.49 & -4.27 & -0.26 & -0.42 & -0.01 & -0.36 & 13.65 & 0.02 \\
$Z$ & -26.42 & 39.9 & 46.43 & 6.11 & 17.23 & -6.49 & -13.97 & -7.58 & -5.49 \\
\hline$R$ & 3.68 & -43.43 & -3.07 & 2.70 & -0.65 & -0.11 & -0.29 & 0.14 & 0.02 \\
Surplus & -4.68 & 44.43 & 4.07 & -1.70 & 1.65 & -0.89 & -0.71 & -1.14 & 0.98 \\
$\Delta B$ & -1 & +1 & +1 & +1 & +1 & -1 & -1 & -1 & +1 \\
\hline
\end{tabular}

TABLE 7. Present-value financing using the mean estimates of posterior draws from the model where all fiscal instruments respond to debt. Shocks normalized to raise or lower debt by 1 unit. Rows for $G, T^{k}, T^{l}, T^{c}$, and $Z$ sum to Surplus; rows for $R$ and Surplus sum to $\Delta B$. 


\begin{tabular}{ccccccc}
\hline \multicolumn{1}{c}{ 1976Q1-2008Q1 } & \multicolumn{2}{c}{ 1989Q1-2008Q1 } & \multicolumn{2}{c}{ 1993Q1-2008Q1 } \\
& Mode & SD & Mode & SD & Mode & SD \\
\hline$\gamma$ & 2.3 & 0.46 & 2.4 & 0.47 & 2.5 & 0.57 \\
$\kappa$ & 1.8 & 0.4 & 2.1 & 0.45 & 1.9 & 0.43 \\
$h$ & 0.52 & 0.079 & 0.5 & 0.095 & 0.69 & 0.085 \\
$s^{\prime \prime}$ & 5.4 & 0.26 & 5.3 & 0.25 & 5.2 & 0.25 \\
$\delta_{2}$ & 0.4 & 0.13 & 0.5 & 0.23 & 0.35 & 0.17 \\
$\rho_{a}$ & 0.96 & 0.02 & 0.9 & 0.033 & 0.85 & 0.056 \\
$\rho_{c}$ & 0.65 & 0.033 & 0.63 & 0.041 & 0.52 & 0.052 \\
$\rho_{l}$ & 0.98 & 0.015 & 0.98 & 0.02 & 0.97 & 0.024 \\
$\rho_{i}$ & 0.69 & 0.063 & 0.85 & 0.048 & 0.73 & 0.078 \\
$\rho_{g}$ & 0.97 & 0.02 & 0.98 & 0.021 & 0.96 & 0.036 \\
$\rho_{\tau^{k}}$ & 0.91 & 0.033 & 0.88 & 0.06 & 0.8 & 0.085 \\
$\rho_{\tau^{l}}$ & 0.93 & 0.033 & 0.94 & 0.037 & 0.91 & 0.055 \\
$\rho_{\tau^{c}}$ & 0.90 & 0.038 & 0.9 & 0.053 & 0.73 & 0.1 \\
$\rho_{z}$ & 0.87 & 0.046 & 0.83 & 0.07 & 0.85 & 0.072 \\
$\gamma_{g}$ & 0.12 & 0.056 & 0.58 & 0.13 & 0.38 & 0.16 \\
$\gamma_{\tau^{k}}$ & 0.21 & 0.1 & 0.38 & 0.18 & 0.91 & 0.25 \\
$\gamma_{\tau^{l}}$ & 0.17 & 0.07 & 0.21 & 0.09 & 0.18 & 0.1 \\
$\gamma_{z}$ & 0.18 & 0.06 & 0.13 & 0.07 & 0.24 & 0.1 \\
$\varphi_{\tau^{k}}$ & 1.4 & 0.059 & 1.2 & 0.32 & 0.9 & 0.26 \\
$\varphi_{\tau^{l}}$ & 0.2 & 0.11 & 0.3 & 0.16 & 0.4 & 0.22 \\
$\varphi_{g}$ & 0.035 & 0.034 & 0.03 & 0.033 & 0.035 & 0.038 \\
$\varphi_{z}$ & 0.13 & 0.075 & 0.15 & 0.084 & 0.13 & 0.073 \\
$\sigma_{a}$ & 0.52 & 0.034 & 0.55 & 0.048 & 0.56 & 0.053 \\
$\sigma_{c}$ & 6.7 & 0.54 & 7.7 & 0.71 & 7.1 & 0.76 \\
$\sigma_{l}$ & 2.5 & 0.39 & 2.2 & 0.33 & 3.1 & 0.57 \\
$\sigma_{i}$ & 6.3 & 0.8 & 7.2 & 1.8 & 4.4 & 0.87 \\
$\sigma_{g}$ & 2.8 & 0.17 & 2.7 & 0.21 & 3.2 & 0.29 \\
$\sigma_{\tau^{k}}$ & 4.7 & 0.29 & 4.5 & 0.36 & 4.3 & 0.39 \\
$\sigma_{\tau^{l}}$ & 2.5 & 0.16 & 2.5 & 0.21 & 2.89 & 0.26 \\
$\sigma_{\tau^{c}}$ & 4.3 & 0.27 & 3.4 & 0.28 & 2.8 & 0.26 \\
$\sigma_{z}$ & 2.8 & 0.18 & 3.1 & 0.26 & 2.4 & 0.21 \\
$\phi_{l c}$ & 0.12 & 0.035 & 0.15 & 0.043 & 0.22 & 0.051 \\
& 0.052 & 0.036 & 0.026 & 0.051 & 0.035 & 0.055 \\
\hline
\end{tabular}

TABle 8. Subsample Estimates. Posterior modes and standard deviations. 

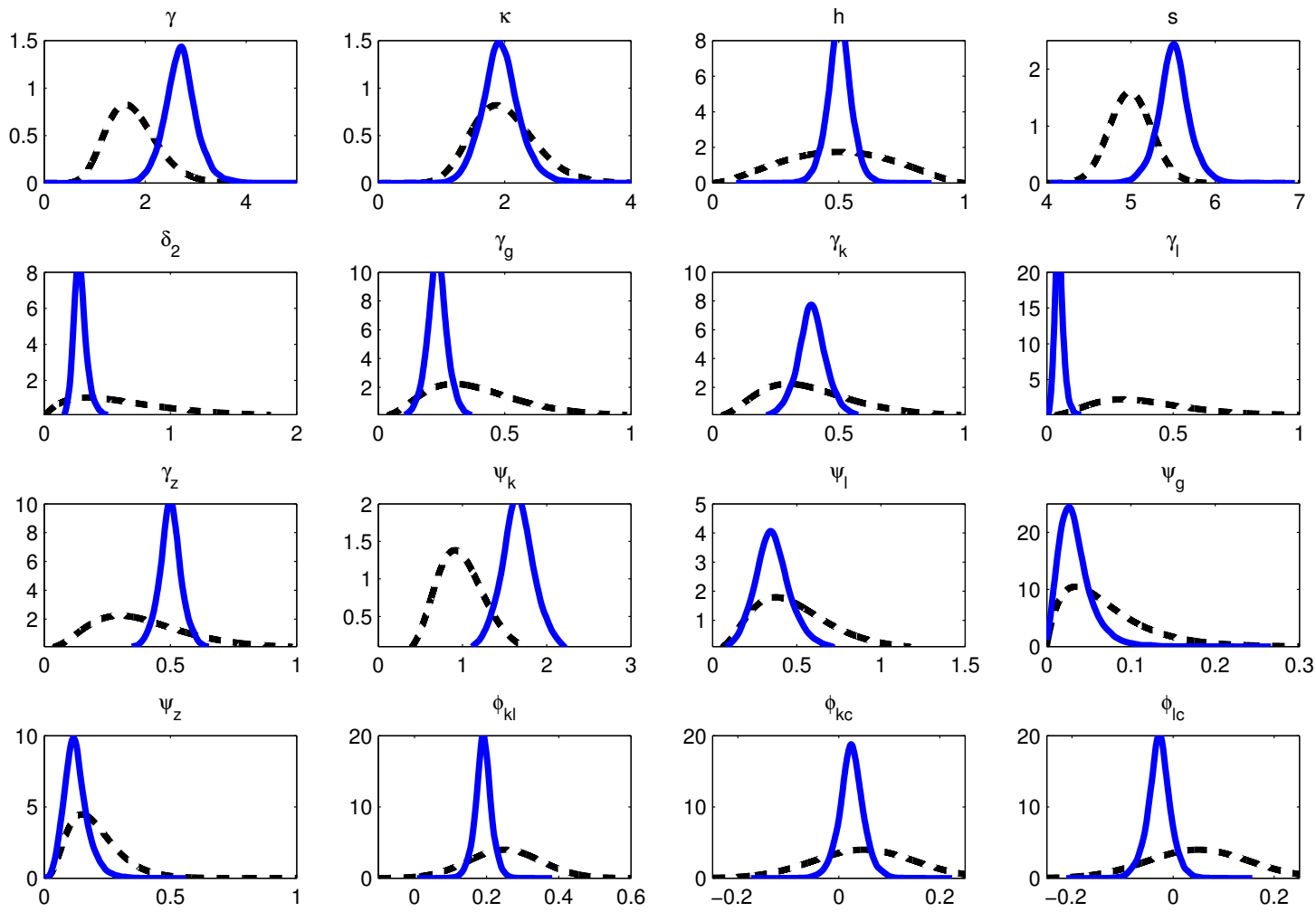

Figure 1. Prior (dashed black) vs. posterior (solid blue) distributions. Posterior distributions are from the model where all fiscal instruments adjust to debt. 

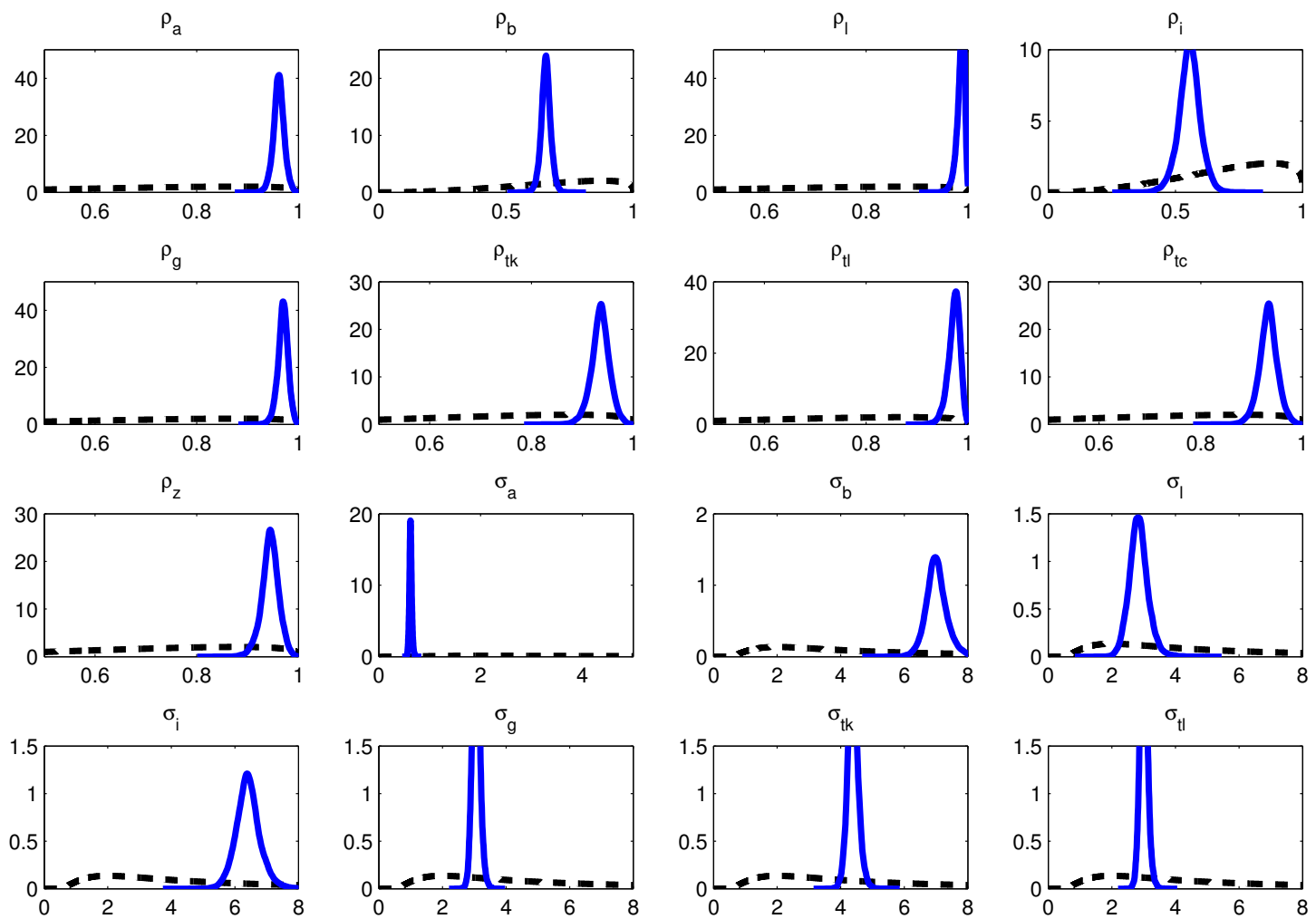

Figure 2. Prior (dashed black) vs. posterior (solid blue) distributions. Posterior distributions are from the model where all fiscal instruments adjust to debt. 

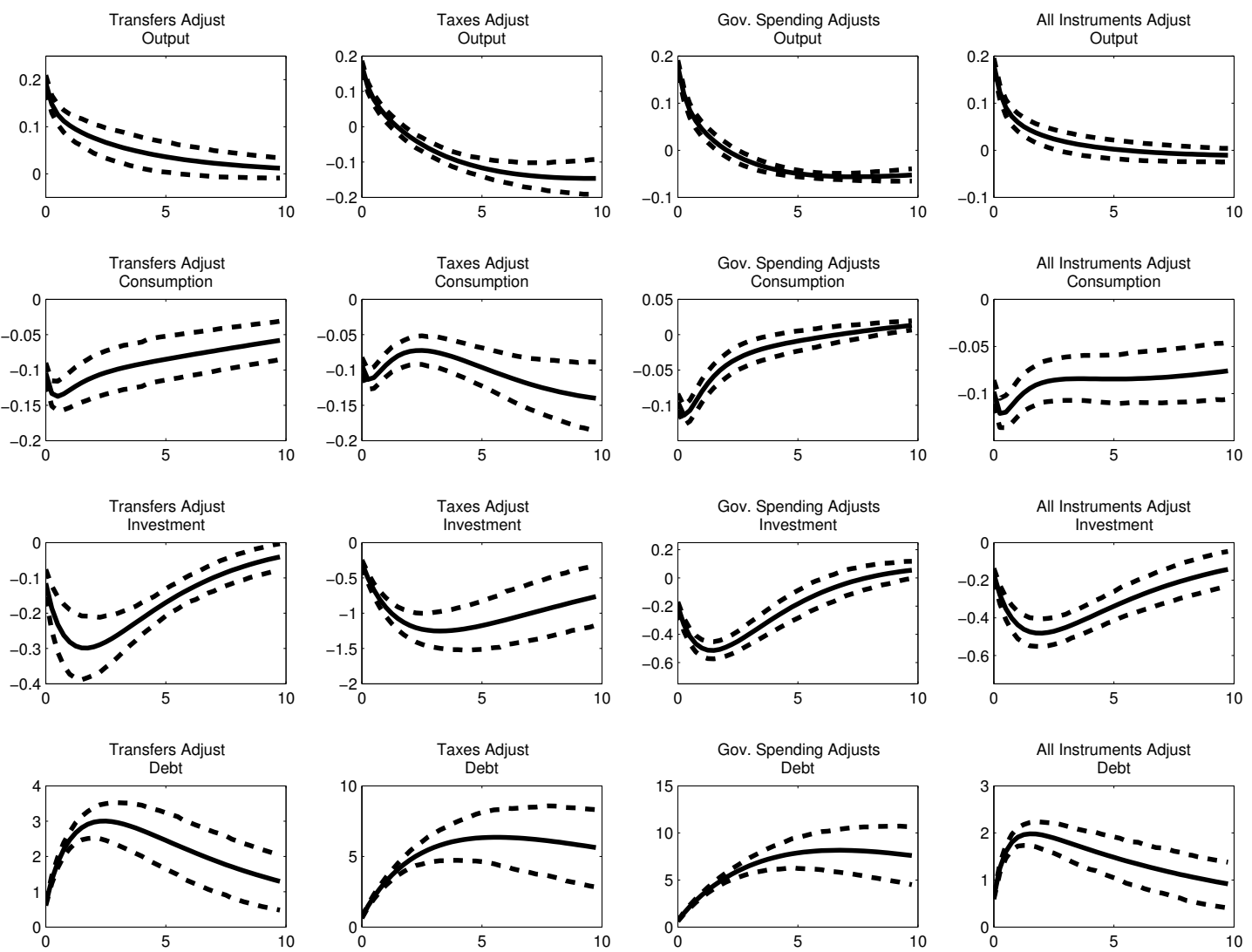

FigURE 3. Estimated impulse responses to a 1 percent increase in government spending shock. The solid line is the mean impulse response; the dashed lines are the 5 percent and 95 percent posterior intervals. X-axis measures years. 

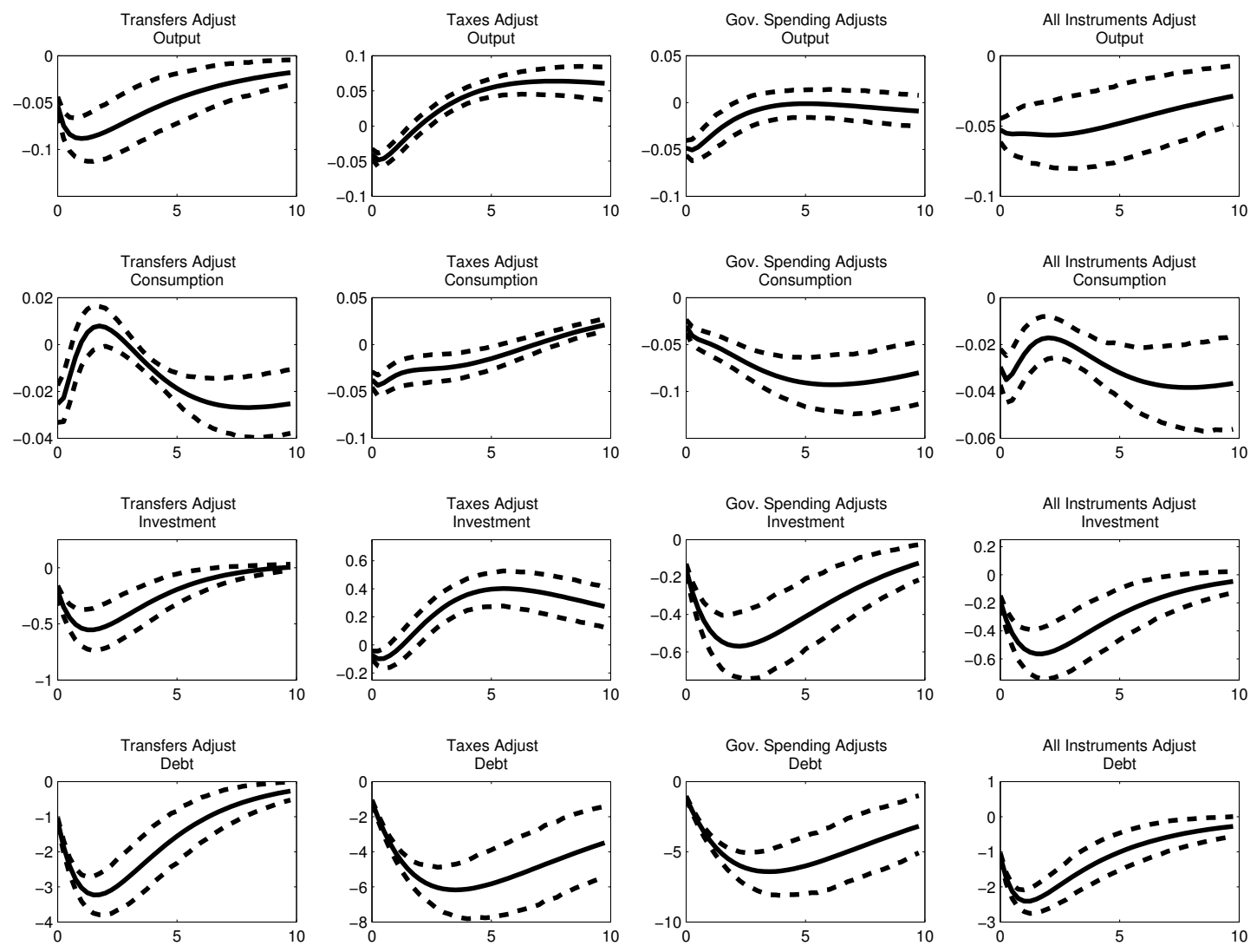

FIGURE 4. Estimated impulse responses to a 1 percent increase in the capital tax rate. The solid line is the mean impulse response; the dashed lines are the 5 percent and 95 percent posterior intervals. X-axis measures years. 

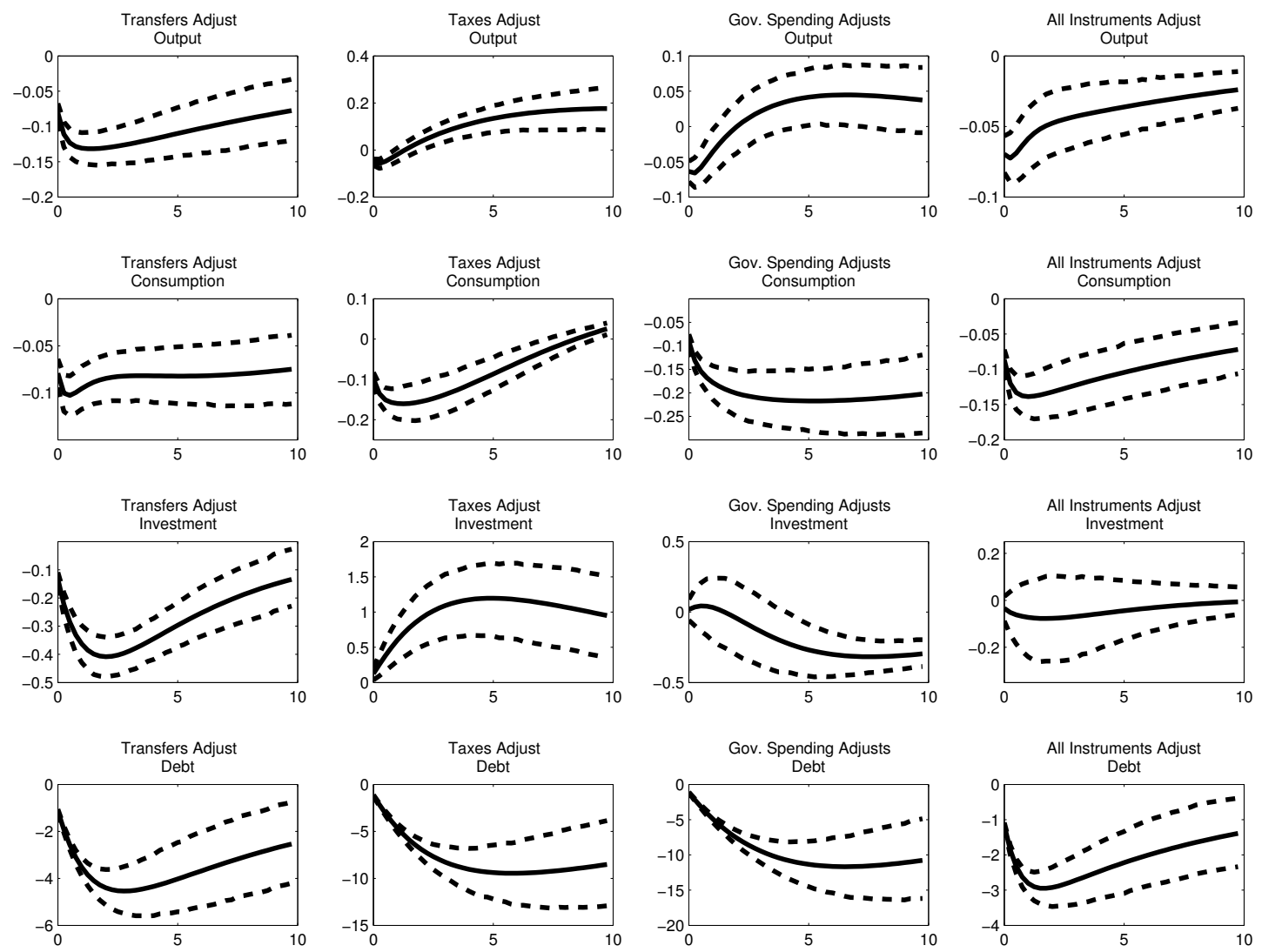

FiguRE 5. Estimated impulse responses to a 1 percent increase in the labor tax rate. The solid line is the mean impulse response; the dashed lines are the 5 percent and 95 percent posterior intervals. X-axis measures years. 

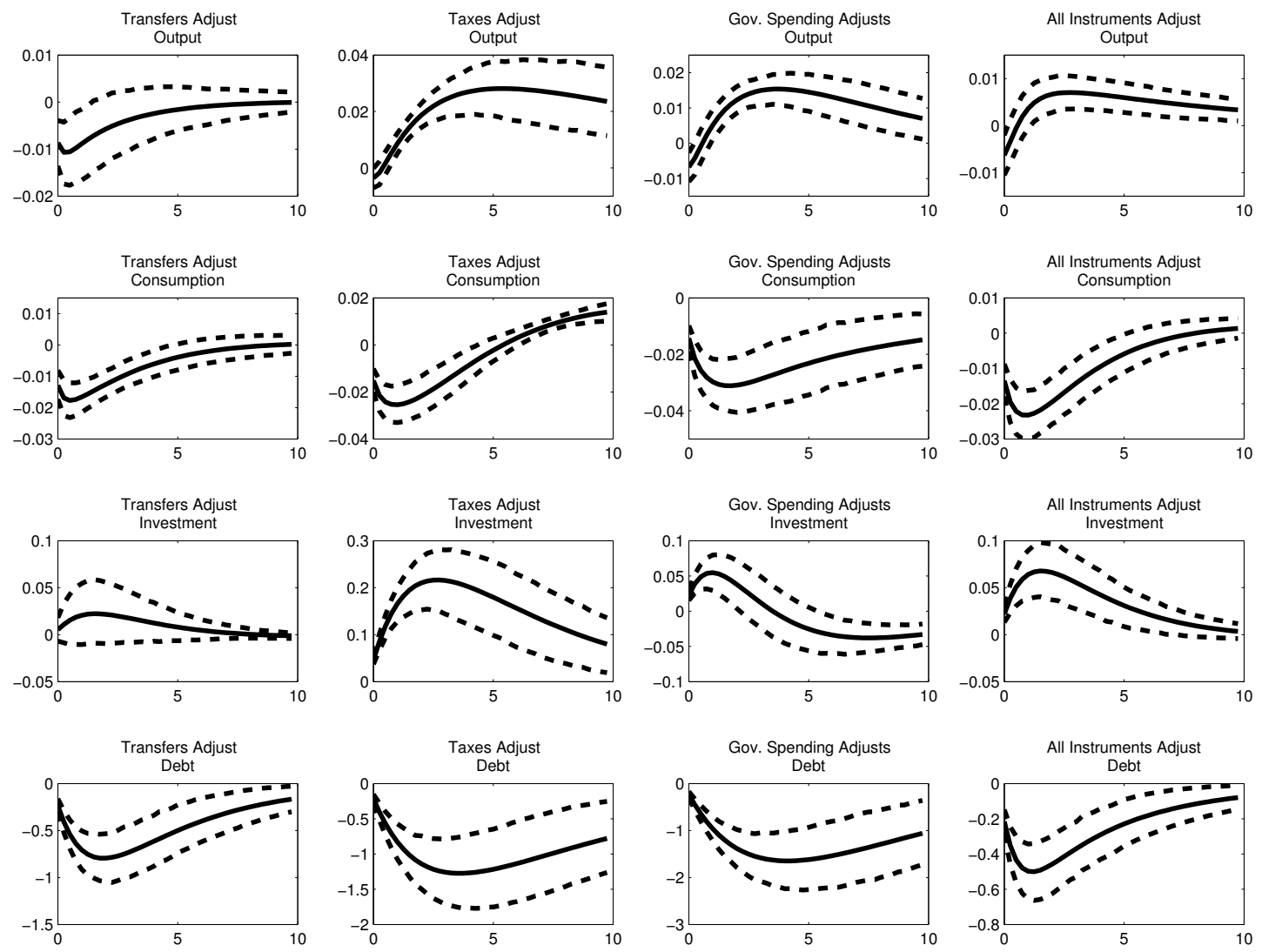

FiguRE 6. Estimated impulse responses to a 1 percent increase in the consumption tax rate. The solid line is the mean impulse response; the dashed lines are the 5 percent and 95 percent posterior intervals. X-axis measures years. 

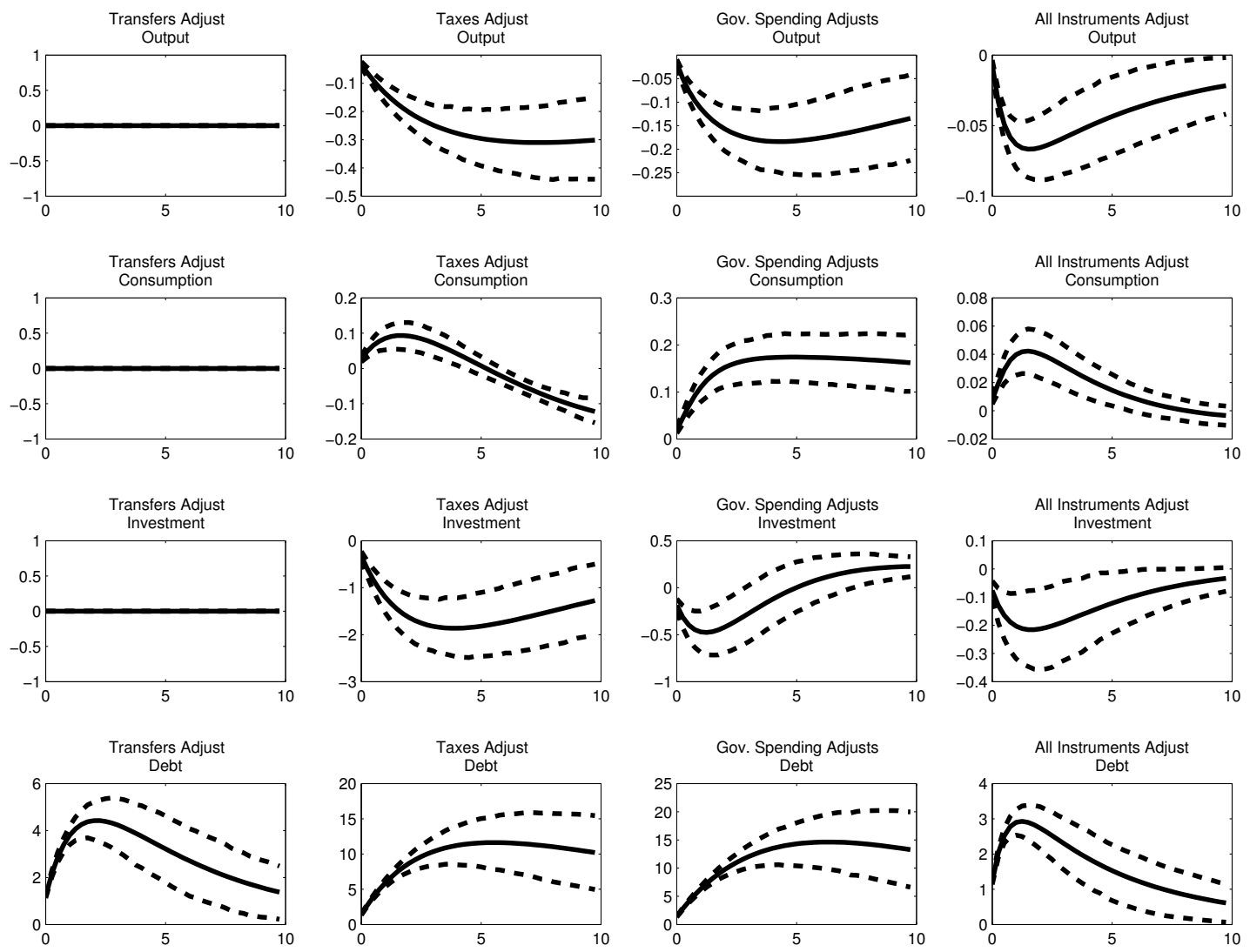

FIGURE 7. Estimated impulse responses to a 1 percent increase in transfers. The solid line is the mean impulse response; the dashed lines are the 5 percent and 95 percent posterior intervals. X-axis measures years. 


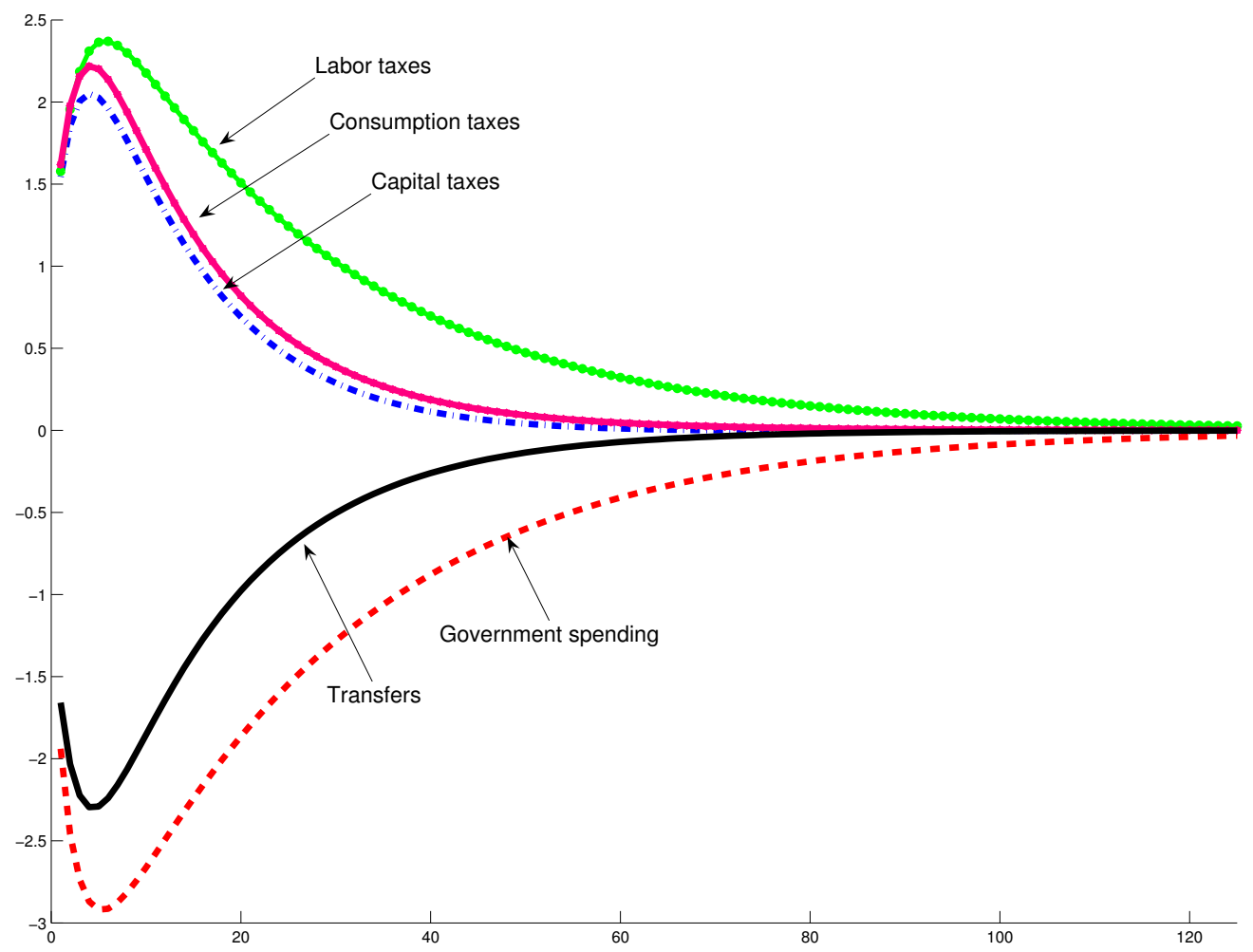

Figure 8. Government debt funding horizons for fiscal shocks using the mean estimates of posterior draws from the model where all fiscal instruments respond to debt. The x-axis units are quarters. 

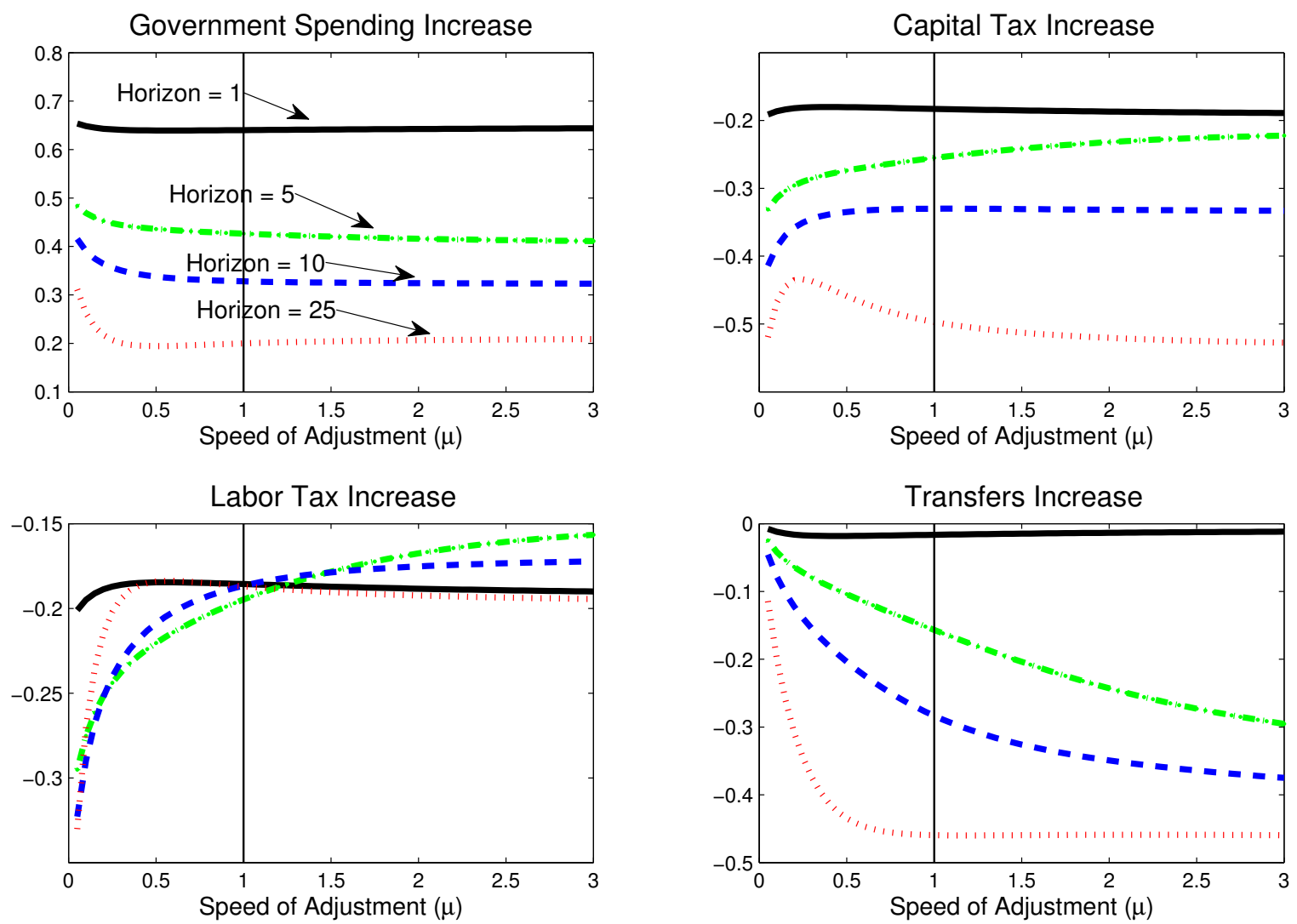

Figure 9. Present-value fiscal multipliers for output at various horizons, as a function of the speed of adjustment of future fiscal variables for shocks to government spending, capital taxes, labor taxes, and transfers. Vertical line at $\mu=1$ is best fitting parameters; $\mu<1$ reduces speed at which debt is retired; $\mu>1$ increases speed at which debt is retired. X-axis measures quarters. 

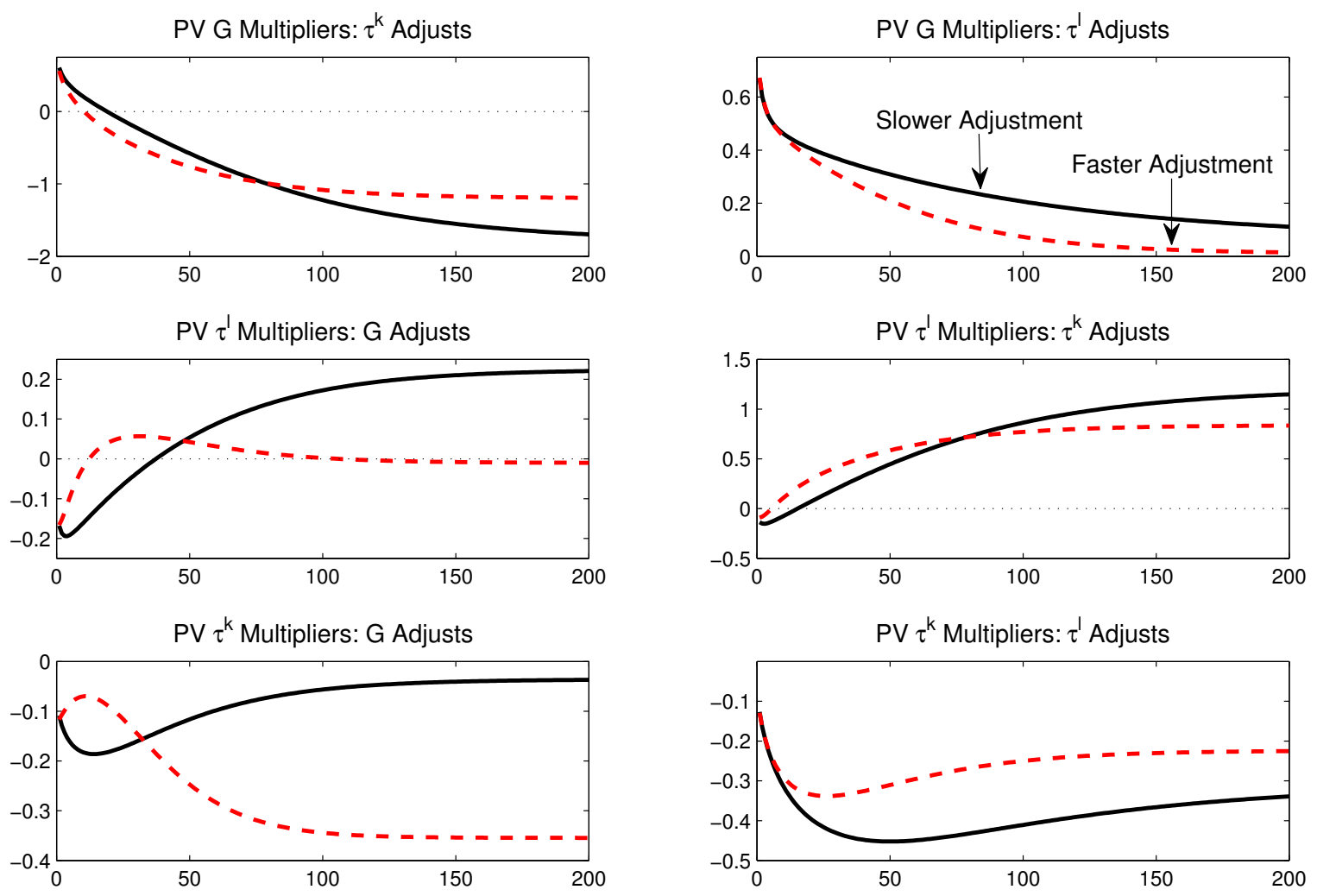

Figure 10. Present-value fiscal multipliers for output as a function of the speed of adjustment of future fiscal variables and which single fiscal variable responds to debt. Uses parameters from best fitting model where all fiscal instruments adjust to debt, but changes fiscal rules so that only a single instrument adjusts and tax shocks are uncorrelated. Slower adjustment (solid lines) scales the relevant fiscal parameter by 0.5 ; faster adjustment (dashed lines) scales relevant fiscal parameter by 2.0. X-axis measures quarters. 


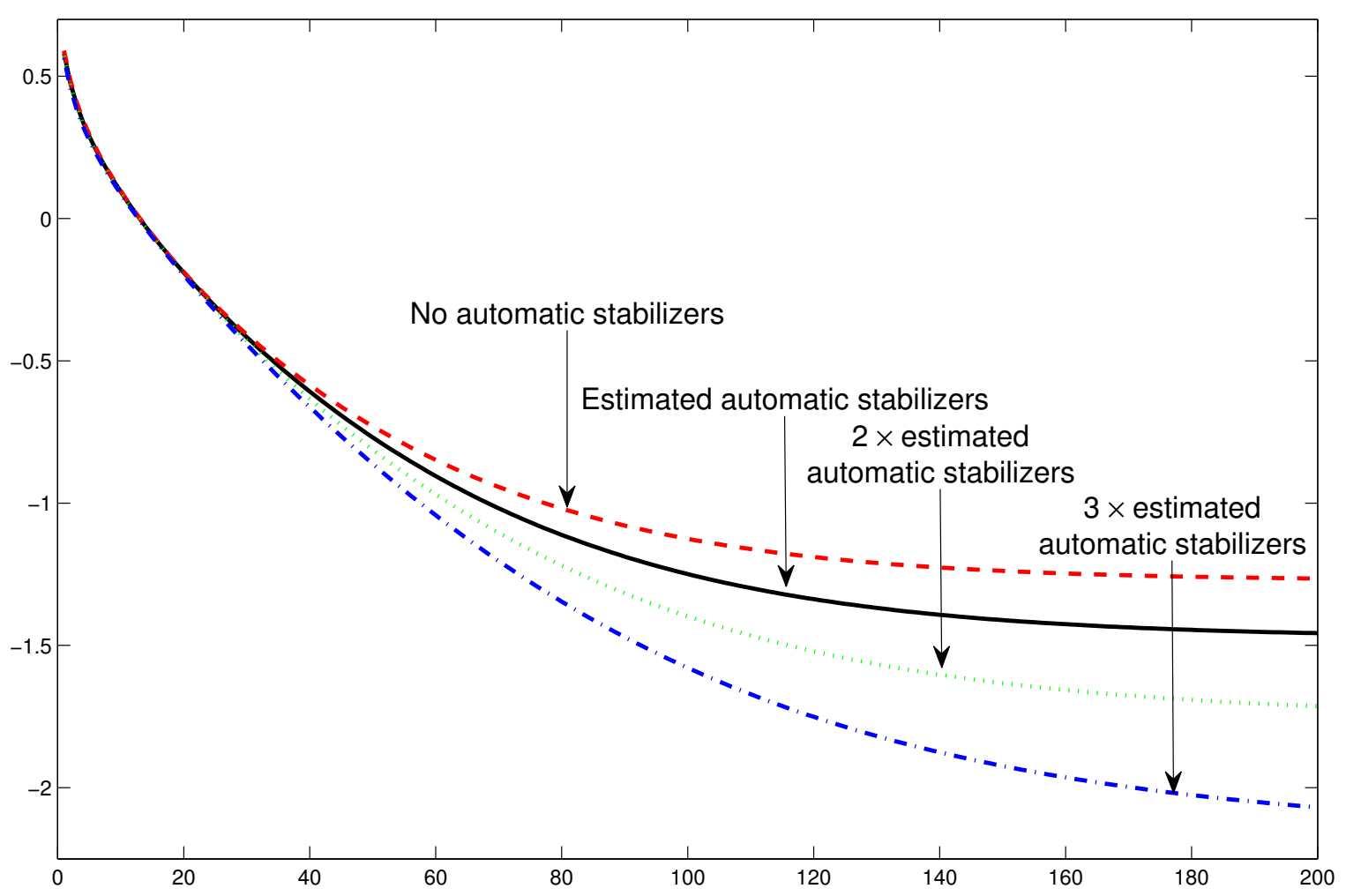

Figure 11. Present-value government spending multipliers for output as a function of the degree of "automatic" responsiveness of fiscal variables to contemporaneous output fluctuations when only capital taxes adjust to stabilize debt. Uses parameters from best fitting model where all fiscal instruments adjust to debt. No automatic response (dashed line); estimated responses (solid line); twice the estimated responses (dotted line); three times the estimated responses (dotted-dashed line). X-axis measures quarters. 


\section{REFERENCES}

An, S., And F. Schorfheide (2007): "Bayesian Analysis of DSGE Models," Econometric Reviews, 26(2-4), 113-172.

Aschauer, D. A. (1989): "Is Public Expenditure Productive?," Journal of Monetary Economics, 23(2), 177-200.

BArro, R. J. (1974): “Are Government Bonds Net Wealth?," Journal of Political Economy, 82(6), 1095-1117.

Baxter, M., and R. G. King (1993): "Fiscal Policy in General Equilibrium," American Economic Review, 83(3), 315-334.

Blanchard, O. J. (1985): "Debts, Deficits, and Finite Horizons," Journal of Political Economy, 93(2), 223-247.

Blanchard, O. J., and R. Perotti (2002): "An Empirical Characterization of the Dynamic Effects of Changes in Government Spending and Taxes on Output," Quarterly Journal of Economics, 117(4), 1329-1368.

Botman, D., D. Laxton, D. Muir, and A. Romanov (2006): "A New-Open-EconomyMacro Model for Fiscal Policy Evaluation," IMF WP/06/45.

Braun, R. A. (1994): "Tax Disturbances and Real Economic Activity in the Postwar United States," Journal of Monetary Economics, 33(3), 441-462.

Christiano, L. J., M. Eichenbaum, and C. L. Evans (2005): "Nominal Rigidities and the Dynamic Effects of a Shock to Monetary Policy," Journal of Political Economy, 113(1), 1-45.

Christiano, L. J., M. Eichenbaum, and S. Rebelo (2009): "When Is the Government Spending Multiplier Large?," Manuscript, Northwestern University.

Chung, H., And E. M. Leeper (2007): "What Has Financed Government Debt?," NBER Working Paper No. 13425.

Cochrane, J. H. (1999): "A Frictionless View of U.S. Inflation," in NBER Macroeconomics Annual 1998, ed. by B. S. Bernanke, and J. J. Rotemberg, pp. 323-384. MIT Press, Cambridge, MA.

Coenen, G., and R. Straub (2004): "Non-Ricardian Households and Fiscal Policy in an Estimated DSGE Model of the Euro Area," Manuscript, European Central Bank.

Cogan, J. F., T. Cwik, J. B. Taylor, and V. Wieland (2009): "New Keynesian versus Old Keynesian Government Spending Multipliers," Manuscript, Stanford University.

Congressional Budget Office (2009): An Analysis of the President's Budgetary Proposals for Fiscal Year 2010, vol. June. CBO, Washington, D.C.

Cox, W. M., and E. Hirschiorn (1983): "The Market Value of U.S. Government Debt: Monthly, 1942-1980," Journal of Monetary Economics, 11(2), 261-272.

Davig, T., And E. M. Leeper (2009): "Monetary-Fiscal Policy Interactions and Fiscal Stimulus," Manuscript, Indiana University. 
Eggertsson, G. (2009): "Can a Tax Cut Deepen the Recession?," Manuscript, Federal Reserve Bank of New York.

Favero, C. A., And F. Giavazzi (2007): "Debt and the Effects of Fiscal Policy," Manuscript, IGIER (Universita' Bocconi).

Fernandez-Villaverde, J., and J. F. Rubio-Ramirez (2004): "Comparing Dynamic Equilibrium Economies to Data: A Bayesian Approach," Journal of Econometrics, 123(1), $153-187$.

Forni, L., L. Monteforte, and L. Sessa (2009): "The General Equilibrium Effects of Fiscal Policy: Estimates for the Euro Area," Journal of Public Economics, 93(3-4), 559-585.

Gali, J., J. D. Lopez-Salido, and J. Valles (2007): "Understanding the Effects of Government Spending on Consumption," Journal of the European Economic Association, 5(1), 227-270.

Geweke, J. (1999): "Using Simulation Methods for Bayesian Econometric Models: Inference, Development, and Communication," Econometric Reviews, 18(1), 1-73.

- (2005): Contemporary Bayesian Econometrics and Statistics. John Wiley and Sons, Inc., Hoboken, NJ.

Giorno, C., P. Richardson, D. Roseveare, and P. van den Noord (1995): "Estimating Potential Output, Output Gaps and Structural Budget Balances," Economic Working Papers No. 152, OECD.

Jones, J. B. (2002): "Has Fiscal Policy Helped Stabilize the Postwar U.S. Economy?," Journal of Monetary Economics, 49(4), 709-746.

JudD, K. L. (1985): "Short-Run Analysis of Fiscal Policy in a Simple Perfect Foresight Model," Journal of Political Economy, 93(2), 298-319.

KAmps, C. (2007): "Dynamic Scoring in an Estimated DSGE Model of the U.S. Economy," Manuscript, European Central Bank.

Kim, J. (2000): "Constructing and Estimating a Realistic Optimizing Model of Monetary Policy," Journal of Monetary Economics, 45(2), 329-359.

Kumhof, M., And D. Laxton (2008a): "The Global Integrated Monetary Fiscal Model," Manuscript, International Monetary Fund.

— (2008b): "A Party Without a Hangover? On the Effects of U.S. Government Deficits," Manuscript, International Monetary Fund.

Laxton, D., and P. Pesenti (2003): "Monetary Policy Rules for Small, Open, Emerging Economies," Journal of Monetary Economics, 50(5), 1109-1146.

Leeper, E. M. (1991): "Equilibria Under 'Active' and 'Passive' Monetary and Fiscal Policies," Journal of Monetary Economics, 27(1), 129-147.

Leeper, E. M., And C. A. Sims (1994): "Toward a Modern Macroeconomic Model Usable for Policy Analysis," in NBER Macroeconomics Annual 1994, ed. by S. Fischer, and J. J. Rotemberg, pp. 81-118. MIT Press, Cambridge, MA. 
Leeper, E. M., T. B. Walker, And S.-C. S. YAng (2009): "Fiscal Foresight and Information Flows," NBER Working Paper No. 14630.

Leeper, E. M., And S.-C. S. YAng (2008): "Dynamic Scoring: Alternative Financing Schemes," Journal of Public Economics, 92(1-2), 159-182.

Monacelli, T., and R. Perotti (2008): "Fiscal Policy, Wealth Effects, and Markups," NBER Working Paper No. 14584.

Mountford, A., And H. Uhlig (2009): "What Are the Effects of Fiscal Policy Shocks?," forthcoming in Journal of Applied Econometrics.

Perotti, R. (2004): "Estimating the Effects of Fiscal Policy in OECD Countries," Manuscript, IGIER-Universita' Bocconi.

Ratto, M., W. Roeger, and J. In'T Veld (2006): "Fiscal Policy in an Estimated Open-Economy Model for the Euro Area," European Commission Economic Papers No. 266.

Ravn, M. O., S. Schmitt-Grohe, and M. Uribe (2007): "Explaining the Effects of Government Spending Shocks on Consumption and the Real Exchange Rate," NBER Working Paper No. 13328.

Romer, C., And J. Bernstein (2009): The Job Impact of the American Recovery and Reinvestment Plan. Obama Transition Team, Washington, D.C., January 9.

Sargent, T. J., And N. Wallace (1981): "Some Unpleasant Monetarist Arithmetic," Federal Reserve Bank of Minneapolis Quarterly Review, 5(Fall), 1-17.

Schmitt-Grohe, S., And M. Uribe (2008): "What's 'News' in Business Cycles?," NBER Working Paper No. 14215.

Sims, C. A. (1994): "A Simple Model for Study of the Determination of the Price Level and the Interaction of Monetary and Fiscal Policy," Economic Theory, 4(3), 381-399.

- (1998): "Econometric Implications of the Government Budget Constraint," Journal of Econometrics, 83(1-2), 9-19.

- (2001): "Solving Linear Rational Expectations Models," Journal of Computational Economics, 20(1-2), 1-20.

Smets, F., And R. Wouters (2003): "An Estimated Dynamic Stochastic General Equilibrium Model of the Euro Area," Journal of the European Economic Association, 1(5), 1123-1175.

- (2007): "Shocks and Frictions in U.S. Business Cycles: A Bayesian DSGE Approach," American Economic Review, 97(3), 586-606.

Uhlig, H. (2009): "Some Fiscal Calculus," Manuscript, University of Chicago.

WeIL, P. (1987): "Love Thy Children: Reflections on the Barro Debt Neutrality Theorem," Journal of Monetary Economics, 19(3), 377-391.

Woodford, M. (1995): "Price-Level Determinacy Without Control of a Monetary Aggregate," Carneige-Rochester Conference Series on Public Policy, 43, 1-46.

YAnG, S.-C. S. (2005): "Quantifying Tax Effects Under Policy Foresight," Journal of Monetary Economics, 52(8), 1557-1568. 